\title{
Upstream internationalization process: Roles of social capital in creating exploratory capability and market performance
}

\author{
Yong Kyu Lew ${ }^{\text {a }}$, Rudolf R. Sinkovics ${ }^{\text {a,*, }}$, Olli Kuivalainen ${ }^{\text {b }}$ \\ ${ }^{a}$ Comparative $\mathcal{E}$ International Business Research Centre (CIBER), Manchester Business School, The University of Manchester, \\ United Kingdom \\ ${ }^{\mathrm{b}}$ School of Business, Lappeenranta University of Technology, Finland
}

\section{A R T I C L E I N F O}

\section{Article history:}

Received 30 December 2011

Received in revised form 28 February 2013

Accepted 4 March 2013

\section{Keywords:}

Exploratory capability

Market performance

Network tie

Social capital

Trust

Upstream internationalization

\begin{abstract}
A B S T R A C T
This paper investigates to what extent resource governance of international ventures affects dynamic capability and market performance in the high-tech firms' internationalization process. We examine the non-equity-based international network collaborations of high-tech firms as forms of strategic resource seeking within the internationalization process. Within the context of upstream technology collaborations by international software and hardware firms, this paper proposes and empirically examines the impact of resource governance mechanisms (i.e. trust-building and behavioral monitoring) on the exploratory capabilities of firms. The findings indicate that building trust in the internationalization process of network ventures contributes to the firm-level exploratory capabilities and, in turn, market performance. Furthermore, this paper tests the moderating effects of structural capital on the capability-performance relationship. The relationship is stronger when network relationships existed before the inception of the international technology alliance. We also find a negative moderating effect from the existence of an actual alliance and from network duration on the relationship between exploratory capability and market performance. To this end, the longevity of the alliance may not always be something firms should aim for. The paper highlights the criticality of relational and structural capital in the internationalization process and the importance of exploratory capability for creating radical innovation in high-tech industries.
\end{abstract}

(c) 2013 Elsevier Ltd. All rights reserved.

\section{Introduction}

To what extent does resource governance of international ventures affect dynamic capability and market performance in the internationalization process of high-tech firms? Does structural capital moderate the relationship between dynamic capability and market performance? Tackling these questions are critically important as the imperatives of the high-velocity market prompt geographically and culturally isolated firms to form international technological collaborations and network relationships. Resource exchange governance (which can include mechanisms such as trust-building and behavioral monitoring) in international network collaborations are of crucial importance as resource acquisition and protection is a double-edged sword in the internationalization process of firms. International network collaborations such as international

\footnotetext{
* Corresponding author. Tel.: +44 1613068980.

E-mail addresses: yongkyu.lew@mbs.ac.uk (Y.K. Lew), Rudolf.Sinkovics@manchester.ac.uk (R.R. Sinkovics), Olli.Kuivalainen@lut.fi (O. Kuivalainen).

URL: http://www.personal.mbs.ac.uk/rsinkovics
} 
technology alliances (ITAs) are frequently used governance structures, and individual participants (i.e. firms) in the network ventures should develop technology resource exchange governance in their international business (Yilmaz \& Kabadayi, 2006). Technological interactions between these firms within the international networks enable the exchange of complementary technology resources, facilitating innovation-creating dynamic capabilities (see e.g. Buckley \& Casson, 2009; Eisenhardt \& Martin, 2000; Griffith \& Harvey, 2001; Sapienza, Autio, George, \& Zahra, 2006; Teece, 2007; Teece, Pisano, \& Shuen, 1997).

The business network internationalization process model emphasizes the role of social capital such as trust-building from the relational network perspective (Johanson \& Vahlne, 2006, 2009; Vahlne, Ivarsson, \& Johanson, 2011). Particularly, from a value chain perspective, the recent paper of Johanson and Vahlne (2009, p. 1427) points out: 'while there is considerable research on global supply chain development, little of it appears in international business (IB) journals compared with the number of studies on market-seeking internationalization'. However, to date, the majority of interfirm studies in IB have focused on vertical relationships in downstream value chains. Although the idea of relationship building through social capital (e.g. trust) is relatively well established in the literature, this type of research deals with international manufacturer-distributor or exporting manufacturer-importing distributor relationships from a downstream relationship perspective. A large amount of value is generated through the technology-related activities of firms at the upstream end (e.g. design, basic and applied research and development (R\&D) and commercialization efforts) (Ahuja \& Katila, 2001; Mudambi, 2007; Teece, 1996). Indeed, considering the importance of technology and complementary resources that endow firms with their strategic position (Teece \& Pisano, 1994), studies on the behavior of technology-based and innovative firms are not as common in the IB literature as would be expected (Cheng \& Bolon, 1993; Griffith, Cavusgil, \& Xu, 2008; Tsang et al., 2008).

Nevertheless, recent empirical research on the internationalization process has primarily focused on the market growth of multinational (Buckley \& Casson, 2009) and small and medium sized enterprises (Heide, 1994); incremental behavior of firms for exploiting market opportunity (Johanson \& Vahlne, 2006); incremental internationalization paths taken by firms such as exports, licensing, subsidiaries, and wholly owned ventures (Malhotra \& Hinings, 2010); and downstream activities (Mudambi \& Navarra, 2004). Work focusing on market-seeking activities fails to uncover firms' technology-resource-seeking and upstream internationalization behavior (Johanson \& Vahlne, 2009).

This paper develops an integrative model, drawing from internationalization, social capital, and dynamic capability theories. Then, it empirically examines to what extent resource governance of international ventures affects dynamic capability and market performance in the high-tech firms' internationalization process. Particularly, we focus on the roles of social capital in creating dynamic capability in the internationalization process and achieving market performance. Within the research context of technological network collaborations in upstream value chains, we select key software and hardware companies in the rapidly growing mobile computing market (see Appendix A). Within short time periods, internationalization via ITAs allows software and hardware firms in the upstream value chain to complement each other by combining unique resources and developing innovation-creating capabilities (Harrison, Hitt, Hoskisson, \& Ireland, 2001; Jaworski, Kohli, \& Sahay, 2000; Kotabe \& Swan, 1995; Shapiro \& Varian, 1999; Teece, 1996). We test our hypotheses by using partial least squares (PLS) structural equation modeling (SEM) based on the up-to-date survey data from 110 high-tech firms forming international network ventures.

Overall, our contribution to the existing literature is threefold. Firstly, this paper contributes to an empirical explanation of the extent to which resource governance mechanisms affect heterogeneous firms' own dynamic capabilities within the upstream internationalization process and as a result, market performance. Secondly, this paper extends the recent theory of business network internationalization process (see e.g. Santangelo \& Meyer, 2011) by introducing the resource-protective mechanism and dynamic capabilities into the internationalization process model. Particularly, in the context of the explosively growing mobile computing industries (see Appendix A), we find that relational capital (i.e. trust building) has a positive effect on exploratory capability. Our findings provide a deep understanding of how strategic resource-seeking firms' relational capital is of critical importance to network ventures' upstream internationalization process. Finally, we also find that structural capital (i.e. network specific experience) has a significant moderating effect on the relationship between exploratory capability and market performance. Thus, this paper affirms the importance of social capital and when using business network terms, network insidership, for the upstream internationalization of network ventures, thereby supporting the recently theorized business network internationalization process model of Johanson and Vahlne (2009).

\section{Conceptual background}

\subsection{Business network internationalization process}

The internationalization process model (Johanson \& Vahlne, 1977; Johanson \& Wiedersheim-Paul, 1975), widely known as Uppsala model, is characterized as a firm's dynamism of market commitment by means of the gradual market knowledge acquisition and learning. Particularly, a firm prefers entering a foreign market which has shorter psychic distance from its home country in the internationalization process as the distance is a kind of a manifestation of uncertainty. For this reason, the initial internationalization process model focuses on market opportunity seeking firms' incremental behaviors in the internationalization process (Johanson \& Vahlne, 1990). Nevertheless, the liability of foreignness (e.g. entry to a greater psychic distance market) could be overcome by closely collaborating with local network participants (Johanson \& Wiedersheim-Paul, 1975). In a similar vein, Johanson and Vahlne's (2006) paper highlights the network perspective in that 
they view a foreign market as a network of embedded firms. Following this view, it is unavoidable for a firm's headquarters and/or its subsidiaries to involve in the network in the internationalization process (Ciabuschi \& Martin, 2011; Yamin \& Anderson, 2011).

The most recently revised internationalization process model takes a relational network perspective (Figueira-de-Lemos, Johanson, \& Vahlne, 2011; Johanson \& Vahlne, 2009; Santangelo \& Meyer, 2011; Vahlne et al., 2011). For instance, Uppsala scholars revisit the concept of a firm's resource commitment decisions, replacing it with relationship commitment and including social capital concepts (e.g. trust and commitment). As for international network relationships, relational norms play a lubricating role when social actors (e.g. insiders) are involved (Coviello \& Munro, 1997; Johanson \& Vahlne, 2009). This relational network perspective offers a better understanding of firms' behavior in the international technology-resourceseeking process. Additionally, from the behavioral perspective, social capital, representing the sum of the resources accrued by a firm via connections between and within networks (see e.g. Koka \& Prescott, 2002), explains the relational resource exchange mechanisms between collaborative international partners.

The updated internationalization process model also points out the criticality of international strategic alliances in IB research: 'joint ventures (JVs) and strategic alliances are modes that are much more commonly used today [than] previously' (Johanson \& Vahlne, 2009, p. 1420). For us, this claim partly echoes Hagedoorn's (2002) work, which illustrates an upward trend in newly formulated non-equity-based technology alliances in the high-tech industry, but a downward trend in JVs within R\&D partnerships from the 1960s to the 1990s: Hagedoorn (2002, p. 481) interprets this downward trend in equitybased technology alliances as follows: 'In particular contractual forms of partnering had become an important instrument of inter-firm collaboration. If one considers the specific trend for RED partnerships during the past four decades, one arrives at a similar conclusion'. Indeed, non-equity-based technology ventures such as ITAs are the emerging form of network collaboration within the internationalization process of firms in the high-tech industry.

\subsection{Interfirm resource governance}

\subsubsection{Social capital}

Firms cannot keep their entire set of resources in-house and at the same time capture all of the market opportunities available in global high-velocity environments (Johanson \& Vahlne, 2009; Ohmae, 1989). However, a firm, as a repository of knowledge, has unique technological capabilities that differentiate it from other firms (Kogut \& Zander, 1992). Due to knowledge tacitness (Inkpen, 2000; Kogut \& Zander, 1993), the more high-tech and knowledge-intensive the industry, the more complex are the technological knowledge transfers between partnering firms. In this vein, firms that develop technologically complex products can obtain complementary external resources so as to overcome technological difficulties and risks (Mitchell \& Singh, 1996; Shapiro \& Varian, 1999). In the network context, resource complementarity can lead to resource dependence on a partner when a firm makes an effort to acquire complementary resources so as to attain a competitive advantage (Richey, Daugherty, \& Roath, 2007). External linkages such as ITAs allow firms to obtain complementary resources and create value (Harrison et al., 2001; Teece, 1996; Teece et al., 1997).

Recent interfirm studies in diverse business and management fields highlight social capital between partners. These studies in interfirm research refer to social exchange theory in social psychology (e.g. Blau, 1964; Levine \& White, 1961). More recent works in management (e.g. Adler \& Kwon, 2002; Nahapiet \& Ghoshal, 1998) and social psychology (e.g. Coleman, 1988; Lavie, 2007) are frequently referred to in the IB literature. Particularly, Nahapiet and Ghoshal (1998) regard social capital as a bundle of embedded resources in the network of relationships, and offer a typology in the form of relational (e.g. trust, norms, obligation, identification), cognitive (e.g. shared codes and languages), and structural capital (e.g. network ties and configuration). Social capital affects the resource exchange in dyadic network relationships (Tsai \& Ghoshal, 1998). In this study we focus on two types of social capital, i.e. relational and structural capital. First, relational capital can be seen as a core of the social capital concept. For example, some scholars have begun to use the term relational norms interchangeably with social capital in a rather collective sense (see e.g. Griffith, Yalcinkaya, \& Calantone, 2010; Kale, Singh, \& Perlumutter, 2000; Liu, Ghauri, \& Sinkovics, 2010; Sarkar, Echambadi, Cavusgil, \& Aulakh, 2001). In other words, relational norms reside in network relationships as an intangible form of socialized capital. The relational view offers a better understanding of firms' behaviors in the international strategic resource-seeking process. Relational capital such as trust can be distinguished from structural capital such as network ties and social interactions (Inkpen \& Tsang, 2005; Nahapiet \& Ghoshal, 1998; Tsai \& Ghoshal, 1998).

Second, we focus on structural capital; this type of social capital can be described as repetitive behaviors between connected social actors, i.e. firms (Coleman, 1988; Lavie, 2007; Nahapiet \& Ghoshal, 1998) and it can also play an important role in the upstream internationalization process. For instance, strong structural connections between network partners can produce dense resource exchange and routines between collaborative partners (Capaldo, 2007; Dyer \& Singh, 1998; Gulati, Lavie, \& Singh, 2009; Zollo, Reuer, \& Singh, 2002).

\subsubsection{Behavioral monitoring}

Relational capital can be seen as a governance mechanism in collaboration between partners in ITAs (e.g. Blomqvist, Hurmelinna, \& Seppänen, 2005). A group of interfirm governance studies, however, emphasizes the hazards of knowledge leakage in conjunction with partners' opportunism (Conner \& Prahalad, 1996; Das \& Rahman, 2010; Madhok, 1995; Oxley, 1997; Oxley \& Sampson, 2004). 
Transaction cost economics (Williamson, 1979, 1981) presumes that partners engage in opportunistic behaviors (e.g. moral hazard, adverse selection, and holdup) due to bounded rationality (Berthon, Pitt, Ewing, \& Bakkeland, 2003; Faems, Janssens, Madhok, \& van Looy, 2008; Granovetter, 1985). This line of research explains the transaction costs residing in latent contractual hazards between firms. Monitoring can be used as a control mechanism to curb exchange partner opportunism and clarify the exchange process in the international network relationship (Heide, Wathne, \& Rokkan, 2007). Herein behavioral monitoring indicates a process control mechanism based on a legal contract to attain anticipated outcomes, e.g. monitoring development resource allocation schedules, or resource quality. From a behavioral economics perspective, the use of behavioral monitoring can be justified as a means to protect against opportunism. Some empirical studies indicate that behavioral monitoring is an effective governance mechanism for international network partners to suppress opportunism (e.g. Heide et al., 2007), in case there is complex resource exchange (e.g. Bello \& Gilliland, 1997), power asymmetry (e.g. Jean, Sinkovics, \& Cavusgil, 2010), or interfirm dependence (e.g. Yilmaz \& Kabadayi, 2006). Particularly, behavioral monitoring can be used when the partnering firms have high levels of process observability and a good understanding of the technological resource transfer process (Kirsch, Sambamurthy, Ko, \& Purvis, 2002). As such, behavioral monitoring based on a contract could be developed. These protective and deterrent governance mechanisms can complement the change dimension in the recently developed internationalization theory, which highlights the role of learning and social capital, e.g. trust building (Johanson \& Vahlne, 2009).

\subsection{Dynamic capabilities}

The dynamic capabilities framework is a vital tool in understanding the long-term competitiveness of the firms (Adner \& Helfat, 2003; Ambrosini \& Bowman, 2009; Eisenhardt \& Martin, 2000; Helfat et al., 2007; Lawson \& Samson, 2001; Teece, 1996, 2007; Teece \& Pisano, 1994; Teece et al., 1997; Winter, 2003). According to Teece et al. (1997), dynamic capabilities refer to the firm's ability to develop its asset base and build new operational-level capabilities. Eisenhardt and Martin (2000, p. 1107) define dynamic capability as the firm's 'processes to integrate, reconfigure, gain and release resources-to match and even create market change'. In the current competitive setting firms need to continuously innovate their current products and services and develop new ones in order to be successful. Firms may develop these internally, may acquire the necessary skills and capabilities externally or develop them in close collaboration with its network partners. Technological collaborations between international networks of partners allow them to exchange complementary technology resources, facilitating innovation-creating dynamic capabilities (Buckley \& Casson, 2009; Teece \& Pisano, 1994). Consequently, dynamic capabilities can be seen as a consequence of certain bonding (or governance) mechanisms between the firm's internalized network resources (e.g. absorptive capacity) (Cohen \& Levinthal, 1990; Lavie, 2006; Mowery, Oxley, \& Silverman, 1996).

In the recent literature, several authors have categorized dynamic capabilities (e.g. Ambrosini \& Bowman, 2009; Teece, 2007). Examples of dynamic capabilities are building a partner and industry contact network to sense capabilities (sensing), the recruitment and organization of managers needed to coordinate value-creating activities (seizing) and reinventing business processes and designing business models (reconfiguration) (e.g. Ellonen, Jantunen, \& Kuivalainen, 2011; Teece, 2007). March (1991) makes a distinction between exploratory and exploitative capabilities and describes the former focusing on searching and applying for new options. Hence, exploration is a term which refers to the search and pursuit of completely new knowledge and skills in product development (Zhou \& Wu, 2010). Classifications of various types of exploratory capabilities have also been used to describe various types of dynamic capabilities; one example of which could be the distinction between product development and market-related exploratory capabilities (Lisboa, Skarmeas, \& Lages, 2011). There are fewer empirical studies of the links between operational-level practices/capabilities and/or processes and the formation of dynamic capabilities, however. One of the exceptions is by Newey and Zahra (2009), who study the interaction between operational capability (product/service development) and a dynamic capability (product portfolio planning and management) within a specific value network of biotech firms. Their proposition is that organizational capabilities influence firm evolution and the interactions between operating and dynamic capabilities are important.

In an international strategic alliance or partnership context too, dynamic capabilities have been studied much less frequently. Griffith and Harvey (2001) study global dynamic capabilities from the power perspective in international business networks but their focus is on downstream internationalization. Their key suggestion is that possession of internal and external assets provides a firm a more powerful position in an international business partnership, which, in its turn, enables them to develop dynamic capabilities. However, they do not study performance consequences of dynamic capabilities per se. There are many studies of dynamic capabilities and internationalization, such as that of Nachum (2003), who focuses on exploitative and exploratory capabilities and their roles in overcoming the liability of foreignness among exporting firms, and that of Jantunen, Puumalainen, Saarenketo, and Kyläheiko (2005), who study reconfiguration capabilities and international performance and found this link to be positive and significant. However, in general, the extant literature takes an exporting or unspecified outward internationalization perspective when focusing on dynamic capabilities and internationalization. In contrast, as pointed out above, our interest is in the mechanisms (e.g. trust-building) that enable firms to learn from their ITAs and develop their exploratory (dynamic) capabilities. In summary, the above discussion suggests that the current literature helps us in the formation of the definitional basis of the dynamic capabilities and in their linkage to performance but it does not cover the researched relationship between operational governance mechanismrelated capabilities and dynamic capabilities in the context of ITAs. 


\section{Hypotheses}

Unlike previous internationalization process research, this paper takes rather different perspectives in the development of its model and hypotheses. Firstly, we view firms' complementary resource acquisition endeavors through collaborations with overseas network partners (i.e. non-equity-based ITAs) as a crucial part of their innovation-oriented internationalization process (Cantwell \& Narula, 2001; Hagedoorn, 2002; Henderson \& Clark, 1990). For this reason, outward R\&D offshoring activities and equity-based JVs are outside of our research boundaries. This paper focuses on the technology-resourceseeking firm's upstream behaviors in terms of resource dependence and trust building within an internal network (e.g. among collaborating partners in ITAs). At the same time, we incorporate behavioral monitoring into the network collaboration process, taking the calculative behaviors of economic actors (firms) into account (Carson, Madhok, \& Wu, 2006; Das \& Teng, 2002).

Secondly, we view governance mechanisms as being embodied in network governance structures/forms/modes (e.g. non-equity-based alliances) within the internationalization process that occurs through network collaborations. Hence, we take the view that collaborative firms ought to develop affective (relational) and/or protective (contractual) resource governance mechanisms in order to manage their cross-border resource exchange arrangements (Hoetker \& Mellewigt, 2009) and thus attain their individual strategic goals. Here, external resource governance mechanisms can be described as the capabilities/skills that provide firms with the ability to manage these resource exchange arrangements. For example, they could include the ability to govern via contracts/monitoring or via the building of trust. All in all, previous research has identified both trust and contracts as critical success factors for upstream partnerships, for example those focusing on R\&D collaboration. Often these two mechanisms co-exist with and complement each other (see e.g. Blomqvist et al., 2005).

Finally, this paper looks upon the dynamic capabilities of a firm as a consequence of bonding (or governance) mechanisms between the firm's internalized network resources (e.g. absorptive capacity) (Cohen \& Levinthal, 1990; Lavie, 2006; Mowery et al., 1996). In this vein, we consider the focal dynamic capability to be the firm-level value-creating exploratory capability, seen from a radical innovation perspective (Eisenhardt \& Martin, 2000; March, 1991) that leads to superior performance.

\subsection{Resource dependence, trust building, and behavioral monitoring}

The literature highlights trust as a representative cooperative mechanism used to manage conflict between collaborating foreign partners (see Svejenova, 2006). Regarding the role of trust in network relationships, the coherent argument in the literature is that the existence of high levels of trust in partnerships not only guarantees less need for safeguard mechanisms against a partner's opportunistic behavior (Gulati \& Nickerson, 2008; Kale et al., 2000; Madhok, 1995), but also interfirm flexibility (Faems et al., 2008) and cooperation (Buckley \& Casson, 1988), thus long-term relationships (Inkpen \& Currall, 2004). As such, 'exchange relationships have a history, and the outcomes of previous business episodes provide a framework for subsequent interaction' (Hallén, Johanson, \& Seyed-Mohamed, 1991, p. 35). Therefore, creating valuable relational capital (e.g. trust) is path-dependent (Ring \& van de Ven, 1994). The behavioral and relational attachments to trust building can be inferred. A high level of interfirm dependence between partners results in more longtem-oriented normative contracting based on the mutual expectation and understanding (Lusch \& Brown, 1996). Thus, dependence on a partner's resources is an antecedent of trust building in the network context (Das \& Teng, 2003). Trust in international network relationships can be regarded as a reliable cooperation between collaborating partners. As relational capital, trust is not built up overnight but over time between dependent partners in network relationships (Gulati \& Sytch, 2008; Madhok, 2006). A firm's resource dependence on its partner influences the building of trust in the internationalization process.

H1. A firm's dependence on a network partner's resources positively influences the building of trust in the international relationship.

From the focal firm's perspective, how to leverage or protect its own technology resources is a critical strategic issue, especially when the firm collaborates with network partners (Mudambi \& Swift, 2011), as resource governance issues arise. Regarding the latter issue of the hoarding/protection of resources, interorganizational governance research based on transaction cost economics regards contract-based monitoring as an appropriate governance mechanism for minimizing the likelihood of opportunism by a partner (Das, 2005; Oxley, 1997; White \& Lui, 2005). From this perspective, social capital such as trust no longer indicates only purely affective relational norms, in that firms are both social and economic actors, pursuing their own benefits from relationships (Blau, 1964; Das \& Teng, 2002; Levine \& White, 1961; Mathieu \& Zajac, 1990). As such, monitoring can play a role in protecting against opportunism and governing the resource exchange process in a network relationship (Anderson \& Gatignon, 1986; Bello \& Gilliland, 1997).

In the context of ITAs, contracting can be important as valuable, rare, inimitable and non-substitutable information is often exchanged. Development processes may be lengthy and require close cooperation, which means that both parties need to invest in the relationship. This kind of embedded network relationship can lead to a long-term specific resource dependence between the network partners (Pfeffer \& Salancik, 1978). Relation-specific adaptations between network 
partners can mean that partner-switching costs are high, increasing the dependence on the partner (Cannon, Achrol, \& Gundlach, 2000; Jacobides, Knudsen, \& Augier, 2006). In particular, a high level of dependency tends to accompany technological collaborations in upstream activities due to the large amount of key task-related information that is exchanged between partners (Gerwin, 2004). In such circumstances, the network partners will understand each other's key resources and processes to a large extent. As such, one may opportunistically take advantage of the embedded relationship. For this reason, based on transaction cost economics (Williamson, 1979, 1981), firms need to adopt deterrence mechanisms against network partners' deceitful exploitation of resources (e.g. hold-up and appropriability) (Contractor \& Ra, 2002; Das, 2005; Gulati \& Singh, 1998; Mayer \& Salomon, 2006). Given a high level of dependence between insiders within a network, behavioral monitoring is a suitable resource governance mechanism (within the internationalization process) from the focal firm's perspective.

H2. A firm's dependence on a network partner's resources positively influences behavioral monitoring in the international relationship.

\subsection{Exploratory capability through resource governance in network collaborations}

A firm's exploratory (value-creating) capability can be seen as a dynamic capability that is crucial to the growth of the firm as it leads to the tapping of new markets and the generation of new revenue streams (Chesbrough, 2003; Jaworski et al., 2000). Resource complementarity and bounded rationality also spur firms to seek the resources they need by collaborating with other firms. These kinds of dynamic capabilities allow firms that operate internationally to sense and seize available external resources, integrate them with their own, and reconfigure/transform their previous processes into new ones, leading to innovation (Teece, 2007; Teece \& Pisano, 1994). The existence of strong exploratory capabilities, built through external linkages/alliances, thus provides the firm with innovation-creating opportunities and long-term competitive advantage (Eisenhardt \& Martin, 2000; March, 1991).

Blyler and Coff (2003) propose that social capital is a necessary, though not sufficient, condition for dynamic capabilities. We pointed out earlier that social capital is related to inter and intrafirm networks that are governed by trust and/or contracts. Trust denotes expectations about what others will do in situations that are not, and often cannot be, explicitly covered in a contract between the parties (Blomqvist, Hurmelinna-Laukkanen, Nummela, \& Saarenketo, 2008). As such, trust as a form of social capital between network partners plays a critical role in bringing complementary resources within an individual firm's boundary. In addition, resource transaction costs can be lowered through trust-based, self-enforced governance mechanisms (Dyer \& Singh, 1998; Thorgren, Wincent, \& Eriksson, 2011). A high level of trust in a collaborative international network contributes to the transfer of resources between firms in networks; trust between parties also increases the transfer of tacit knowledge. Trust has been found or suggested to be an important success factor in many interfirm cooperation studies focusing on alliances (see e.g. Ariño, de La Torre, \& Smith Ring, 2001). Trust is especially important in an internationalization context as managing international projects is inherently much more difficult than managing domestic ones (Blomqvist et al., 2008). Trust building affects individual firms' exploratory capabilities, which allows them to generate idiosyncratic radical innovation streams, integrating resources that are external and new to the firm with their existing capacity (Eisenhardt \& Tabrizi, 1995; Hill \& Rothaermel, 2003).

H3. In the internationalization process, building trust with a partner positively influences a firm's exploratory capability.

Network collaborations entail the exchange of valuable technology resources, thus developing appropriate network governance mechanisms is the main concern for partnering firms. In particular, contract-based network governance helps to protect firms from their partners' opportunism in uncertain market environments (Carson et al., 2006). As such, behavioral monitoring helps firms to protect themselves from their network partners' opportunistic behaviors (Das \& Rahman, 2010; Sampson, 2004). From a resource exchange control perspective, including a reciprocally predefined conflict resolution process in the contract will allow network partners to resolve anticipated problems and guard them against opportunism (Carson et al., 2006; White \& Lui, 2005). Thus, a contract-based behavioral monitoring process complements trust-based relational governance as the detailed contractual specifications can protect against future uncertainty and ensure cooperative fulfillment (Lorenz, 1999; Poppo \& Zenger, 2002). A standardized mechanism of this sort can help guide firms as to when, what, and how to coordinate and integrate the external resources it receives. However, although contracts provide firms with a visible path (e.g. innovation milestones, strategic planning) in an uncertain innovation journey, they may at the same time hinder innovative behavior, lead to a less visible learning culture in the organization, and negatively influence firms' explorative capabilities. Contractual governance is much more about the exploitation of current operational capabilities than exploratory capabilities. Whereas exploitation involves the development of new knowledge about the firm's current products and markets, and the incremental development of the skills of the firm, exploration consists of questioning existing ideas and developing new knowledge about new products, markets, technologies and skills/capabilities (Lisboa et al., 2011; March, 1991). Excessive control lessens the learning in an ITA and/or makes that learning much more incremental. In such a situation, dynamic capabilities may be less prevalent. 
H4. In the internationalization process, a firm's behavioral monitoring of a partner negatively influences its exploratory capability.

\subsection{Performance, network duration, and prior network ties}

The link between dynamic capabilities and competitive advantage or performance has been suggested in a large number of studies (e.g. Griffith \& Harvey, 2001; Teece, 2007; Teece et al., 1997). The results of the many empirical studies in the IB, innovation, and strategic management literature indicate that exploratory, innovation-creating capabilities influence the market performance of firms (e.g. Bobillo, Sanz, \& Gaite, 2006; Calantone, Cavusgil, \& Zhao, 2002; Vorhies, Morgan, \& Autry, 2009) although the results are often inconclusive (see e.g. the review of Ambrosini \& Bowman, 2009 for this). One reason for inconclusive results can be found in the fact that the conceptual argumentation focusing on the importance of dynamic capabilities is often based on certain contextual competitive characteristic such as heavy global competition and rapidly changing environments and that possessing them in these environments is a necessity for long-term success (e.g. Ambrosini \& Bowman, 2009; Griffith \& Harvey, 2001; Teece, 2007). This means that the role of dynamic capabilities as the drivers of performance varies in different contexts (e.g. Eisenhardt \& Martin, 2000; Teece, 2007). They are, for example, seen as important drivers of performance in those markets where technical change itself is systemic; i.e. multiple innovations must be combined to create products/services that address customer needs (Teece, 2007). This argument fits well to our content of the ITAs as we are focusing on the role of the alliance network in the development of exploratory dynamic capabilities and their role on success.

Dynamic capabilities can be seen impacting a firm's value creation via their impact on its resource base (Ambrosini \& Bowman, 2009). Teece (2007) suggests that dynamic capabilities can be disaggregated into three categories, the capacity to (1) sense and shape opportunities and threats, (2) seize opportunities, and (3) maintain competitiveness by enhancing, combining, protecting and, when necessary, reconfiguring intangible and tangible assets. Hence, dynamic capabilities are tools used to form a long-term sustainable competitive advantage by giving a firm the means to develop radical/breakthrough innovations, for example. From a perspective that innovation is a quest into the unknown that includes examining and exploring technological and market opportunities (Teece, 1996), the exploration and application of radical new ideas allows firms to create a new product, process, and/or business model (Chesbrough, 2007; Galbraith, 1982; March, 1991). Thus, firms that aggressively explore technological resources that are new to them will achieve highly innovative outcomes (Atuahene-Gima, 2005; Yalcinkaya, Calantone, \& Griffith, 2007; Zhou \& Wu, 2010). Exploring radical innovation processes can be uncertain and risky, but can also change the rules of the game, thereby enabling the development of breakthrough technologies (e.g. wireless internet), and new business models combined with new products/services (e.g. online software applications distributed through app stores). Value-creating exploratory capabilities allow a firm to launch innovative products on new markets (e.g. Yalcinkaya et al., 2007), for example. Eventually this would create new revenue streams, increasing market share and sales. Furthermore, highly innovative products in new markets can enhance the overall reputation of a firm.

In summary, a firm possessing exploratory capabilities which enables it to sense, and seize opportunities from its ITA partner(s) and which enables the firm continuously to include new aspects into its technological development processes and products, and able to acquire entirely new managerial and organizational skills should be able to develop new difficult-toimitate combinations from its internal and external resource base on an international basis (see e.g. Griffith \& Harvey, 2001). Firms can achieve overall organizational effectiveness by continuously aligning and realigning internalized resources with their own existing capacity. This should lead to competitive advantage and eventually to superior performance consequences, as for example, Jantunen et al. (2005) found out that firms reconfiguring capabilities had a positive and significant effect on performance and Yalcinkaya et al. (2007) found out that exploration capabilities influence positively market performance.

H5. A firm's exploratory capability positively influences its market performance.

Drawing from the social capital theory, the existence of strong structural connections between ITA partners allow for developing and strengthening interorganizational bonding mechanisms through dense resource exchange (Coleman, 1988; Inkpen \& Tsang, 2005; Nahapiet \& Ghoshal, 1998; Tsai \& Ghoshal, 1998). The existence of longer network duration between network partners allow them to spend more time on collaborations through social interactions (Marsden \& Campbell, 1984; Tsai \& Ghoshal, 1998), thereby developing relationship-specific routines (Kim, Oh, \& Swaminathan, 2006). For this reason, the effects of exploratory capability on market performance may differ depending on the network tie duration, given the dynamics of high-tech industries. In addition to the need for change and evolution, also the path-dependent nature of the development of resources and capabilities has been highlighted (Teece et al., 1997). In this industry context, ITAs with a relatively long alliance history can contribute to the exploratory capabilities of the firms involved, in that the partners' greater need for technology resources sustains the relationship. A long-lasting network tie will influence the unique bonding mechanism in the relationship (Håkansson \& Snehota, 1995), thus the network history affects a firm's exploratory capability for innovation (Capaldo, 2007; Kanter, 1984; Teece, 1996).

Network tie is representative structural capital as it resonates with the strength of a network relationship between social actors (Nahapiet \& Ghoshal, 1998). In this vein, previous co-operative experience between the partners can help them to develop a mutual understanding and interorganizational routines (Contractor, Woodley, \& Piepenbrink, 2011; Dyer \& Singh, 1998; Gulati et al., 2009; Zollo et al., 2002). On the basis of having a structural connection through prior experience, a 


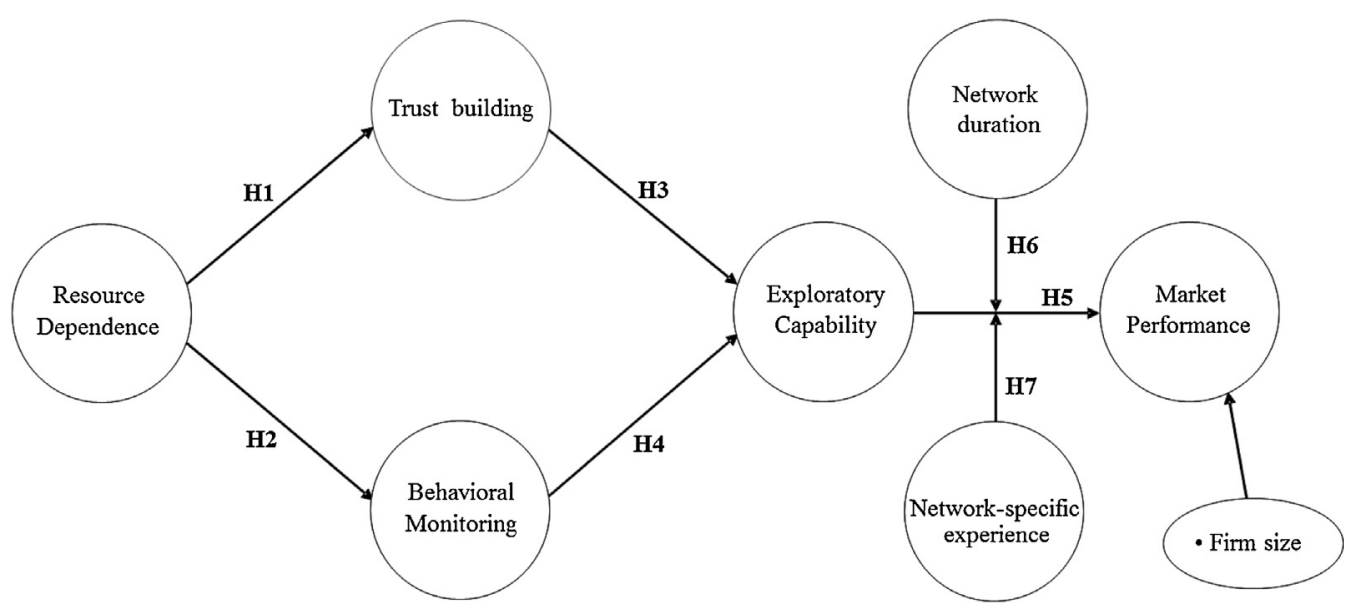

Fig. 1. Hypothesized model.

previous co-operative experience between network partners can expedite the transfer of technology resources in subsequent international relationships. Moreover, in high-velocity high-tech industries, firms may prefer working with previous partners so as to avoid the transaction risks originating from market uncertainty (Podolny, 1994). From the firm's perspective, the firm could have access to technology resources of previous international network partners without spending high transaction costs accompanied by international ventures. For this reason, a preceding network tie contributes to the firm's exploratory capability for competitive advantage and performance. Following this argument, we develop two hypotheses to test moderating effects of structural capital on the relationship between exploratory capability and market performance.

H6. The longer the duration of a network tie, the higher will be the positive impact of exploratory capabilities on market performance.

H7. The existence of a previous network tie before founding an ITA positively influences the impact of exploratory capabilities on market performance.

Fig. 1 illustrates how the seven hypotheses developed in this section fit together into an overall model.

\section{Research methods}

\subsection{Sampling frame and data collection}

Our sampling frame is composed of 350 hardware and 529 software firms in the mobile computing market. We initially developed the sampling frame using publicly available global partner lists of dominant hardware firms (e.g. Intel,

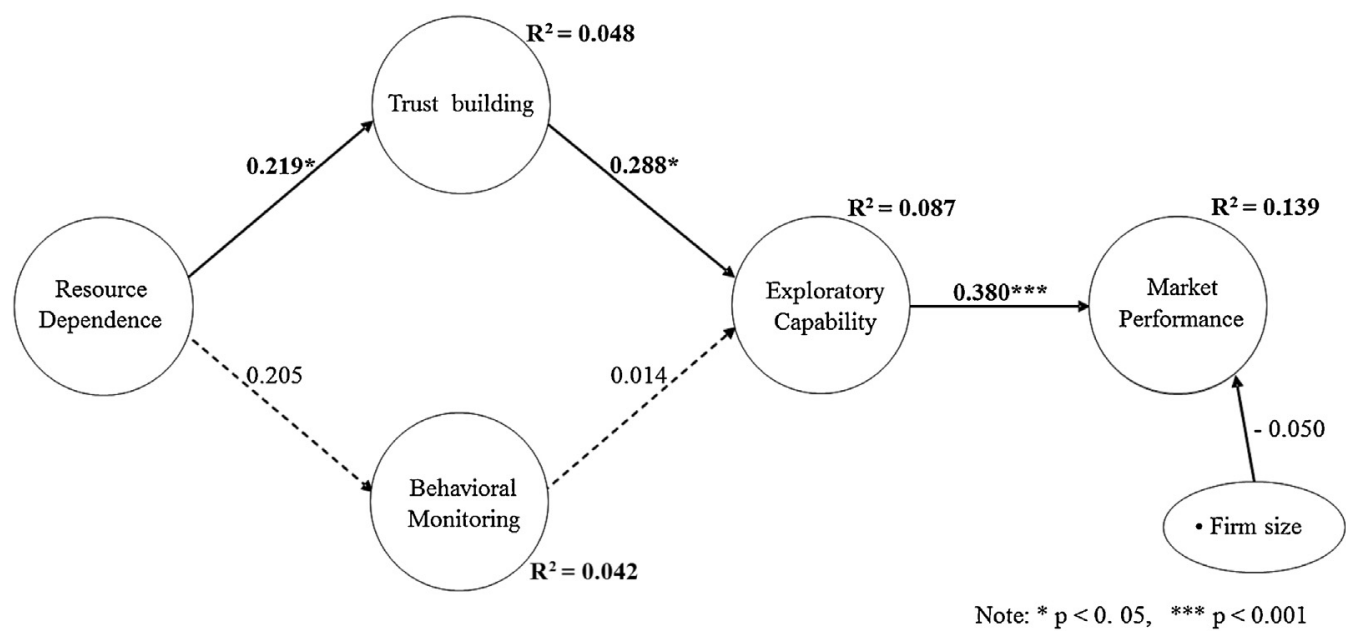

Fig. 2. Assessment of the structural model. 
Table 1

Respondent characteristics.

\begin{tabular}{lcr}
\hline Location of HQs & Number of respondents & $\%$ \\
\hline Taiwan & 42 & 38 \\
United States & 23 & 21 \\
Republic of Korea & 12 & 11 \\
United Kingdom & 6 & 5 \\
India & 5 & 5 \\
China & 4 & 4 \\
Japan & 4 & 4 \\
Finland & 3 & 3 \\
France & 3 & 3 \\
Canada & 2 & 2 \\
Ireland & 2 & 2 \\
Israel & 1 & 1 \\
Morocco & 1 & 1 \\
Norway & 1 & 1 \\
Sweden & 1 & 1 \\
Total & 110 & 100 \\
\hline Alliance duration & Number of respondents & 9 \\
\hline More than 5 years & 25 & 100 \\
4-5 years & 55 & 23 \\
2-3 years & 20 & 50 \\
Less than 2 years & 10 & 18 \\
Total & & 9 \\
\hline
\end{tabular}

Qualcomm, ARM, MIPS, and Texas Instrument) in the market and then complemented it by adding lists of firms exhibiting at the IT events, the Mobile World Congress 2011 and Computex 2011. The key informants were senior managers in charge of ITAs.

We collected the data using online and field surveys. Firstly, we sent e-mails to the 879 firms. Three weeks after the first email, we sent follow-up e-mails to non-respondents and telephoned them. Nine firms refused to respond to the questionnaire and 94 questionnaires were not properly delivered. Next, we collected data at the Computex conference in Taiwan in 2011. 95 firms from the sampling frame were approached and asked to participate. We pre-contacted the participating firms and gathered data via questionnaire-based surveys. 110 valid and completed questionnaires were collected, thus the valid response rate was 14.2\% (110/776). 102 respondents provided us with their titles. 85\% (87/102) of the respondents held top executive positions in their organizations, such as CEO, President, Managing Director, COO, VP, Director, or Senior Manager. The profiling information provided by the key informants allowed us to check the representativeness of the collected data in terms of the respondents' position, and their ability to understand firm internationalization strategies, organizational capabilities, and business performance dimensions in relation to their firms.

The locations of the respondents' headquarters (HQs) are dispersed over 15 countries. 88 of the 110 firms are headquartered in just five countries (42 in Taiwan, 23 in the US, 12 in Korea, 6 in the UK, and 5 in India), making up $80 \%$ of the sample. It is not surprising that the highest number of respondents stems from Taiwan, as the country boasts the world's largest electronics manufacturing services industry in the computer and IT market (Jean et al., 2010; Kishimoto, 2004). The mean network duration is 4.2 years, with 46 respondents being in networks of a longer duration than this and 64 being in networks of a shorter duration. Table 1 shows the locations of the respondents' HQs and the distribution of network durations.

Early-late response bias was examined among the respondents to the online survey by comparing the responses of the early and late respondents on all 21 items in the model, following Amstrong and Overton's (1977) approach. Based on the result of the $t$-test, there were no significant differences in the means of any of the items between the two groups, suggesting that there is no strong non-response bias in our research. We also compared the data collected from the online survey with that from the field survey. There were no significant differences between the two data collection methods.

Following Podsakoff and Organ (1986), common method variance was examined using Harman's one-factor analysis. We conducted unrotated principal components analysis on all measurements, extracting five factors with eigenvalues over 1.0. The results of the analysis revealed that only $23.7 \%$ of the total variance of $69.4 \%$ was explained by the first factor, so no single or general factor emerged. Above and beyond this initial step, we conducted a correlation analysis between 34 of the firms' primary and secondary sales revenue data in the fiscal year 2010. The correlation of these data with those from the survey was $98 \%$, indicating that common method variance does not appear to be a problem in the data.

\subsection{Measures}

Resource dependence is conceptualized as a focal firm's technology resource dependence on its most important foreign network partner. A four-item scale, adapted to the context of international technology network collaborations, was derived 
from Ganesan (1994). Trust building is defined as the degree of trust between a focal firm and its most important foreign partner. Three scales were adapted from Aulakh, Kotabe, and Sahay (1996). Behavioral monitoring is defined as the extent to which a firm monitors the technology resource exchange process performed by its most important network partner, in order to achieve the desired deliverables from the relationship (Aulakh et al., 1996; Heide et al., 2007). We adapted four items from the works of Heide et al. (2007) and Kirsch et al. (2002).

Exploratory capability is defined as a firm's ability to acquire entirely new skills and resources, integrate them with its own internal capacity, and produce innovative products (Teece, 2007). Four items were drawn from the works of Zhou and Wu (2010) and Yalcinkaya et al. (2007).

Market performance is measured by the following six items: sales growth, growth in market share, increased number of official new products launched, increased number of customers, increased reputation in the market, and increased overall performance (Lyles \& Salk, 2007; Robins, Tallman, \& Fladmoe-Lindquist, 2002; Venkatraman \& Ramanujam, 1986).

Two moderating variables are used: network duration and network-specific experience. Network duration is measured by the number of years for which the alliance relationship has existed (Liu et al., 2010; Simonin, 1999). We coded networkspecific alliance experience as 1 if a firm had previously conducted business with its partner before forming the alliance and as 0 otherwise.

We controlled for firm size which is measured by the number of employee. We supposed that firm size influences market performance as bigger firms could have more slack resources, and take more risk in exploring innovative resources than smaller firms (Tsai \& Ghoshal, 1998). Furthermore, bigger firms could have more capacities for and access to exploring resources than smaller firms, thus achieving better market performance.

\section{Results}

We focused on a survey-based methodology and the generalizability of the results. The data were analyzed using PLS path modeling. PLS-SEM is a variance-based and prediction-oriented multivariate approach, but is also suitable for testing exploratory theories or extensions of theories (Henseler, Ringle, \& Sinkovics, 2009; Hulland, 1999). We selected PLS path modeling as the appropriate data analysis technique because of the exploratory nature of combining new theoretical perspectives, which is the internationalization process and its linkage to dynamic capability, and relatively new empirical setting in this paper. PLS-SEM has less stringent assumptions than covariance-based SEM (e.g. LISREL) in that PLS does not require a normal distribution of observations or a large-sized sample (Fornell \& Bookstein, 1982). PLS is a prediction-oriented multivariate approach, but is also suitable for testing exploratory theories (Hair, Sarstedt, Pieper, \& Ringle, 2012; Henseler et al., 2009; Hulland, 1999). Indeed, academics in business and management have recently adopted PLS path modeling as a key analytical method in such areas as IB (e.g. Lages, Silva, \& Styles, 2009; Tsang, 2002) and strategic management (e.g. Gruber, Heinemann, Brettel, \& Hungeling, 2010; Swoboda, Meierer, Foscht, \& Morschett, 2011).

\subsection{Assessment of the measurement model}

Internal reliability was examined via Cronbach's alpha and composite reliability. Four constructs had alpha values above 0.7, while resource dependence has an alpha of 0.675 which is only just below 0.7 (see Appendix B). However, the composite reliability values of all constructs were greater than the threshold of 0.7 (Bagozzi \& Yi, 1998). We measured indicator reliability using outer loadings. The absolute standardized outer loadings were all greater than the acceptable level of 0.5 (Chin, 1988), indicating that reliable measurements are being taken in the model.

Convergent validity was assessed by measuring average variance extracted (AVE). The AVE values of all constructs were greater than the 0.5 threshold, as shown in Appendix B (Fornell \& Larcker, 1981). We examined discriminant validity using AVE and cross-loadings. The values of AVE for each construct were greater than the squared correlations between the constructs (Fornell \& Larcker, 1981), as shown in Table 2. We also assessed discriminant validity by comparing the loading values of each indicator with its cross-loadings with other indicators (Chin, 1988). The cross-loadings were all lower than the indicator loadings, suggesting that there is discriminant validity in the model.

Table 2

Correlations and discriminant validity.

\begin{tabular}{|c|c|c|c|c|c|c|c|}
\hline & & 1 & 2 & 3 & 4 & 5 & 6 \\
\hline 1 & Resource dependence & 0.714 & 0.219 & 0.205 & -0.007 & 0.089 & -0.113 \\
\hline 2 & Trust building & 0.048 & 0.844 & 0.482 & 0.294 & 0.162 & 0.087 \\
\hline 3 & Behavioral monitoring & 0.042 & 0.232 & 0.841 & 0.153 & 0.219 & -0.158 \\
\hline 4 & Exploratory capability & 0.000 & 0.086 & 0.023 & 0.806 & 0.369 & 0.203 \\
\hline 5 & Market performance & 0.008 & 0.026 & 0.048 & 0.136 & 0.727 & 0.027 \\
\hline 6 & Firm size & 0.013 & 0.008 & 0.025 & 0.041 & 0.001 & 1.000 \\
\hline
\end{tabular}

Note: Bold diagonal figures are the square roots of AVE; the figures below the diagonal are the squared correlations; those above are the construct correlations. 
Table 3

Effect size of the latent variables.

\begin{tabular}{lllll}
\hline & $R^{2}$ & CV-C $Q^{2}$ & \\
\hline Trust building & 0.048 & 0.713 & 0.034 \\
Behavioral monitoring & 0.042 & 0.708 & 0.024 \\
Exploratory capability & 0.087 & 0.650 & 0.003 \\
Market outcomes & 0.139 & 0.529 & 0.058 \\
\hline
\end{tabular}

Note: $\mathrm{CV}-\mathrm{C}$, cross-validated communality; CV-R, cross-validated redundancy.

\subsection{Assessment of the structural model}

The predictability of the structural model was analyzed using $R^{2}$ and $Q^{2}$. In particular, we assessed the predictive relevance of the four endogenous constructs using Stone-Geisser's cross-validated $Q^{2}$ (Geisser, 1975; Stone, 1974). The $R^{2}$ values of the four endogenous constructs ranged from 0.042 to 0.139 . The $R^{2}$ values of trust building and behavioral monitoring were relatively lower than those of exploratory capability and market performance. However, the crossvalidated $Q^{2}$ values were all greater than zero. This suggests that the latent has been adequately estimated and thus indicates the predictive relevance of the model (Chin, 1988; Götz, Liehr-Gobbers, \& Krafft, 2010; Tenenhaus, Vinzi, Chatelin, \& Lauro, 2005; Wold, 1975). Table 3 summarizes the $R^{2}$ and $Q^{2}$ values of the latent variables at the structural level.

The hypotheses were tested by looking at the significance of the seven path coefficient estimates in the model. By bootstrapping 5000 cases, we obtained the standardized errors and t-statistics. The assessment of the structural model is illustrated in Fig. 2. The path coefficient from resource dependence to trust building is $0.219(t=2.389, p<0.05)$, supporting H1. Our results thus support the notion that the importance of the existing mechanisms for building trust between the partners increases when a firm is dependent on a partner's resources.

The path coefficient from resource dependence to behavioral monitoring is not significant $($ coefficient $=0.205, t=1.888$ ) so we reject $\mathrm{H} 2$. As for the non-significant relationship, the role of contracts in the development of dynamic capabilities is less clear although trust and contracts (monitoring) are often seen as complementary governance mechanisms (Blomqvist et al., 2005; Lorenz, 1999; Poppo \& Zenger, 2002). The path coefficient from trust building to exploratory capability is 0.288 $(t=2.552, p<0.05)$, which supports H3. Our results show that, in the context of ITAs, building trust with a partner positively influences a focal firm's exploratory capability. Our results support our prediction that the interaction between parties in ITAs results in new knowledge via trust building - as a governance mechanism - and contributes to the firm's development of certain dynamic capabilities. The impact of behavioral monitoring on exploratory capability is not significant (coefficient $=0.014, t=0.106$ ) so $\mathrm{H} 4$ is rejected. Although $\mathrm{H} 4$ was not supported, the result was not contradictory to our expectations either as the path coefficient was close to zero and non-significant. The path coefficient from exploratory capability to market performance is $0.380(t=3.481, p<0.01)$, which supports H5. The results reveal that dynamic exploratory capability is highly related to market performance in the upstream context. However, firm size is not significantly associated with market performance (coefficient $=-0.050, t=0.532$ ). Table 4 shows the results of the path analysis.

Regarding $\mathrm{H} 6$ and H7, we tested whether network duration and network-specific experience (see Fig. 1) moderate the relationship between exploratory capabilities and performance. The $R^{2}$ value of market performance increases to 0.209 when we introduce network duration as a moderating variable. The relationship between exploratory capability and market performance is significantly moderated by network duration. However, the path coefficient from the interaction between exploratory capability and network duration to market performance is negative $(-0.261, t=2.766, p<0.01)$ and contrary to our expectations and consequently $\mathrm{H} 6$ is rejected. In the case of H6, dynamic high-tech industry characteristics may have caused the unexpected result. Taking the newness of the mobile computing market into account, collaboration networks

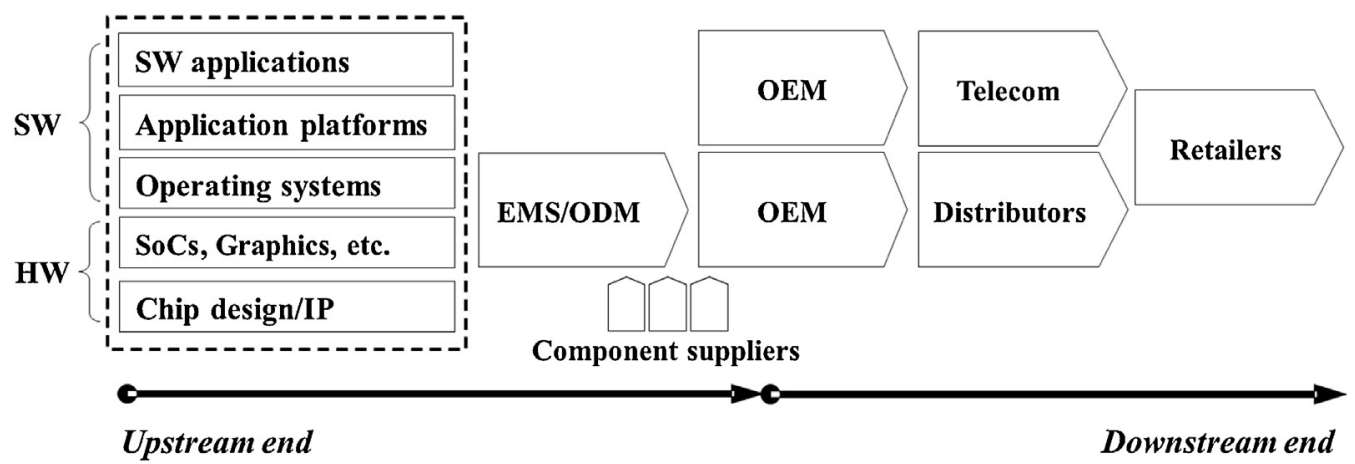

Fig. 3. Value chain of the mobile computing market. 
Table 4

Assessment of path analysis.

\begin{tabular}{|c|c|c|c|}
\hline Paths & Standardized coefficient & t-statistic & Supported? \\
\hline H1. Resource dependence $\rightarrow$ Trust building & $0.219^{*}$ & 2.389 & Yes \\
\hline H2. Resource dependence $\rightarrow$ Behavioral monitoring & 0.205 & 1.888 & No \\
\hline H3. Trust building $\rightarrow$ Exploratory capability & $0.288^{*}$ & 2.552 & Yes \\
\hline H4. Behavioral control $\rightarrow$ Exploratory capability & 0.014 & 0.106 & No \\
\hline H5. Exploratory capability $\rightarrow$ Market performance & $0.380^{* * *}$ & 3.481 & Yes \\
\hline
\end{tabular}

${ }^{*} p<0.05$, (degrees of freedom, 4999).

*** $p<0.001$, (degrees of freedom, 4999).

with a relatively short history may contribute to the firms' exploratory capability for developing new products and services because such partners' more urgent need for technology resources may have necessitated the formation of these relationships.

When network-specific experience moderates the exploratory capability-market performance relationship, the $R^{2}$ value of market performance increases to 0.226 . The path coefficient from the interaction term (i.e. exploratory capability $\times$ netnetwork-specific experience) to market performance is 0.264 . The moderating effect of network-specific experience on the relationship between exploratory capability and market performance is found to be significant and positive $(t=2.320$, $p<0.05)$. Consequently, we accept H7. The results suggest that the existence of previous ties before founding an alliance positively influences the impact of exploratory capability on market performance. This is in line with previous research showing that existing network ties help to incorporate mutual social norms (Contractor et al., 2011; Dyer \& Singh, 1998; Gulati et al., 2009; Zollo et al., 2002) and bring benefits from the earlier co-operation to the current modus operandi. The results of the moderating effects are summarized in Table 5.

\subsection{Post hoc analysis}

The results of the hypothesis tests indicate that resource dependence affects exploratory capability only through trust building (see Fig. 2; Table 4). However, an alternative relationship might exist, in that resource dependence in the internationalization process might induce a firm's exploratory capability. Thus, we compare the results of our original model with a competing model, and in so doing rigorously examine the validity of the findings of the original model (for other applications of this approach, see e.g. Henley, Shook, \& Peterson, 2006; Rong \& Wilkinson, 2011). In our new competing model, we assume that resource dependence has a direct impact on exploratory capability. Based on a bootstrap of 5000 observations, we obtain standard errors and obtain $t$-statistics. The path coefficient from resource dependence to exploratory capability is found to be $-0.078(t=0.673)$, which is not significant. However, the results of the other five paths are consistent with the original model. Table 6 summarizes the results of the analysis.

\section{Discussion}

\subsection{Upstream internationalization process}

We explore whether external resource governance between high-tech firms engaged in the internationalization process influences the focal firm's exploratory capability and performance. Unlike most prior studies on dynamic capabilities and internationalization, we examine the upstream end of the value network within ITAs, specifically highlighting the growing mobile computing market.

Table 5

Moderating effects of network duration and network-specific experience.

\begin{tabular}{|c|c|c|c|}
\hline Hypothesis/path & H5 & H6 & $H 7$ \\
\hline$R^{2}$ of market performance & 0.139 & 0.209 & 0.226 \\
\hline Hypothesis supported? & Yes & No & Yes \\
\hline \multicolumn{4}{|l|}{ Path coefficients } \\
\hline Exploratory capability & $0.380^{* *}(t=3.481)$ & $0.308^{* *}(t=3.135)$ & $0.359^{* * *}(t=3.722)$ \\
\hline Firm size & $-0.050(t=0.352)$ & $-0.016(t=0.135)$ & $-0.030(t=0.287)$ \\
\hline Network duration & - & $-0.084(t=0.922)$ & - \\
\hline Network-specific experience & - & - & $-0.156(t=1.703)$ \\
\hline Exploratory capability $\times$ network duration & - & $-0.261^{* *}(t=2.766)$ & - \\
\hline Exploratory capability $\times$ networ $k$-specific experience & - & - & $0.264^{*}(t=2.320)$ \\
\hline
\end{tabular}


Table 6

Post hoc analysis results.

\begin{tabular}{|c|c|c|c|}
\hline Paths & Standardized coefficient & $t$-Statistic & Significant? \\
\hline Resource dependence $\rightarrow$ exploratory capability & -0.078 & 0.673 & No \\
\hline Resource dependence $\rightarrow$ trust building & $0.219 *$ & 2.073 & Yes \\
\hline Resource dependence $\rightarrow$ behavioral monitoring & 0.205 & 1.669 & No \\
\hline Trust building $\rightarrow$ exploratory capability & $0.300 * *$ & 2.689 & Yes \\
\hline Behavioral control $\rightarrow$ exploratory capability & 0.024 & 0.190 & No \\
\hline Exploratory capability $\rightarrow$ market performance & $0.375^{* *}$ & 3.423 & Yes \\
\hline Firm size $\rightarrow$ market performance & -0.050 & 0.354 & No \\
\hline
\end{tabular}

* $p<0.05$, (degrees of freedom 4999).

** $p<0.01$, (degrees of freedom 4999).

We view exploratory capability as a dynamic capability with which a firm is able to acquire new skills and technologies and develop, choose and utilize new technological approaches within its processes and products. Our study provides support for the proposition that trust building is an important governance mechanism in these kinds of alliances and, hence, we strengthen the arguments in the extant literature and extend them to this specific context (e.g. Eisenhardt \& Tabrizi, 1995; Hill \& Rothaermel, 2003). In a broader context, our results are also in line with Johanson and Vahlne (2009), who suggest that trust persuades people to share information - an issue that is of vital importance in situations of uncertainty. Via the interaction between the two partners, a firm is able to gain more knowledge about its partner's heterogeneous resources and capabilities (Johanson and Vahlne, 2009). Trust can be presented as relational capital as, in practice, it means that there is reliable cooperation between the collaborating partners in the international network relationship (cf. Madhok, 2006). Correspondingly, the ability to build trust with one's alliance partners and to acquire external resources by utilizing this social capital can be seen as a capability of the firm.

The significant relationship between resource dependence and trust building suggests that resource dependence positively influences relational capital in the international relationship. Meanwhile, the lack of empirical support for the paths from resource dependence to exploratory capability via behavioral monitoring in our context could have several causes. As illustrated in Appendix A, the logical product architectures of mobile computing products are somewhat modularized (e.g. software and hardware stacks/layers), and thus the complementary technological modularity between hardware and software products may alleviate the need for behavioral monitoring in network relationships. Another possible reason is that contractual hazards may not be a big concern in ITAs between hardware and software firms. Partly due to the product characteristics and architecture of hardware and software firms, heterogeneous network partners may focus more on managing their interfacing technologies than controlling each other's core technology resources, leading to low levels of behavioral monitoring. In addition, the explorative relationship context (e.g. joint R\&D agreements, co-development contracts, and mutual technology sharing) in this paper is more likely to be horizontal than asymmetric or vertical (e.g. seller-buyer and sourcer-sourcee relationships). In the horizontal network relationship context, the rather intrusive behavioral monitoring may be a less appropriate mechanism of governance than trust.

Thus, we cautiously propose that behavioral monitoring may be related more to the development of exploitative capabilities than exploratory capabilities. Our results regarding both types of governance mechanisms support work such as that of Anand and Khanna (2000), who find that learning effects in alliances are more important in situations where there is greater contractual ambiguity. Teece (2007) argues that 'dynamic capabilities reside in large measure with the enterprise's top management team, but are impacted by the organizational processes, systems, and structures that the enterprise has created to manage its business in the past'. Exploratory capabilities are likely to be prevalent in the context of developing radical innovations as in this case the focus will most likely be on the reconfiguration of existing capabilities and resources. Thus, our study supports the extant body of literature - which suggests that innovation-creating exploratory capabilities influence the market performance of firms (e.g. Bobillo et al., 2006; Calantone et al., 2002; Vorhies et al., 2009) - in the upstream mobile computing context.

\subsection{Importance of structural capital, network tie}

In the case of the significant but unexpected negative moderating effect of the relationship length (network duration) on the relationship between exploratory capability and market performance, it may be case that a long-term relationship creates inertia (Kim et al., 2006), thus hindering exploratory innovative behavior (Levinthal \& March, 1993). The existing alliance partnership may not be able to sustain and foster innovative behavior as it is past its expiration date. For example, the products born out of the focal alliance relationship may now be in decline in subsequent product life-cycles. This interpretation has some support in the extant literature. For example, Ha and Rothaermel (2005) focus on alliances between bio- and pharmaceutical firms and suggest that, in order to optimize alliance performance, firms should carefully assess alternative partners rather than merely turning to partners with whom they have prior alliance experience. In their study, the predicted probability of joint R\&D success decreased with the number of previous partners a firm had had. The results from their study and the present one may provide a cautionary tale for those who advocate that benefits are more likely to be had from working with the same partner. Within the mobile market, it may be beneficial to look for new partners; Nokia's 
recent leap from its Symbian OS alliance to a partnership with Microsoft may be just one example of a firm taking alliancebased competitive dynamics into account and making necessary changes as a result (regarding alliance competition, cf. Silverman \& Baum, 2002).

The significant positive moderating effect from network-specific experience indicates that re-networking with a previous overseas partner contributes to a firm's radical innovation and superior market performance, which can be explained in two ways. First, sequencing between an alliance period and a non-alliance period may help foreign network partners to develop their own heterogeneity, useful in future collaborations (Faems, Janssens, Bouwen, \& Van Looy, 2006). Second, a positive, relationship-specific experience with a prior network partner could influence interorganizational behaviors in subsequent network collaborations, thus expediting the learning process between the partners (Selnes \& Sallis, 2003).

\subsection{Theoretical contributions}

Overall, this paper makes three important contributions to the IB literature. Firstly, it captures both the resource internationalization and internalization of firms, from the perspectives of strategic technology resource management and IB. Given the importance of the business network view, succinctly captured in the recent internationalization literature (Johanson \& Vahlne, 2009), our study focuses on upstream internationalization. This is an important contribution to the IB literature, which has previously predominantly devoted its attention to downstream internationalization. Our findings highlight that value-creating exploratory capability is a crucial dimension of IB research from the technological innovation perspective. A firm's exploratory capability gained through international network collaborations positively influences innovation-creating firm behaviors.

Secondly, in a high-tech context such as the focal mobile computing domain there is a need to sense, seize and reconfigure new capabilities in order to stay competitive. The exploration and application of radical new ideas enables firms to create new products, processes, and/or business models (Chesbrough, 2007; Galbraith, 1982; March, 1991). This creation of value could be done through ITAs (see e.g. Gulati et al., 2009) and this paper explores two complementary governance mechanisms and their role in the development of a firm's exploratory capabilities. Based on the results of this study, it is evident that the ability to create and maintain a partner's trust is more critical than behavioral monitoring or contracting in terms of dynamic capability development and fostering innovation. The results of this study provide support for the propositions of Blomqvist et al. (2008), for example, who focus on the internationalization of technology-intensive born-global firms. One of their suggestions is that trust is relatively more important governance mechanism than contracting when partnerships have been found with the aim to exchange and share valuable information and knowledge (Blomqvist et al., 2008).

Lastly, as far as the new internationalization theory is concerned, the context studied in this paper suggests that governance issues related to a firm's upstream activities are of similar importance to market commitment in the internationalization process of downstream participants. However, the focal point of attention in the upstream context is seemingly technological resource commitment and this dimension contributes significantly to the performance of alliance partners. This study therefore contributes towards an important extension of the existing internationalization theory which has to date mostly highlighted relationships in the downstream value chain context - to the upstream value chain of technology resources and innovation (Griffith et al., 2008; Johanson \& Vahlne, 2009).

\subsection{Practical contributions}

It is difficult for firms to integrate an entire set of resources due to constraining factors such as limited resource-scanning capabilities, time-to-market, and the cost of capital. This paper offers insights for alliance managers, showing that ITAs (e.g. R\&D development contracts, co-development contracts, and technological knowledge sharing) entered into by firms engaged in the innovation (i.e. new product development) process can play a critical role in helping them to develop technologically innovative products at the upstream end of the explosively growing mobile computing market.

The role of trust in the development of exploratory capabilities within an ITA context is important: firms need to develop mechanisms and skills with which they can enhance the trust-building process between them and their partners. This can be seen as a dynamic capability in its own right, whereas the actual trust-building mechanism within the alliance is an operational capability. We encourage managers to consider the learning that goes on within existing alliances and the development of general alliance management skills (cf. e.g. Anand \& Khanna, 2000).

There is a need to recreate value by harnessing existing relationships. The ability to learn and develop with a sense of togetherness and efficiency in international strategic alliances is a dynamic capability which it is imperative for firms to develop and reconfigure, specifically in the upstream, high-technology context. Technology alliances thus offer an opportunity to actively engage in the "race to learn" (Contractor \& Lorange, 2002) and, when evaluated appropriately, provide managerial pointers as to how firms might unlock more value (Ernst \& Bamford, 2005).

\subsection{Limitations and recommendations}

The setting of this empirical study prompts the enumeration of some limitations. Firstly, the generalization of the findings may be limited to the hardware and software industries in the mobile computing market. For this reason, we suggest that future studies test the model in the context of the upstream value chains of various other industry settings. Taking into 
consideration the unsupported moderating effect of network duration in the current model, we recommend controlling for, technological turbulence or the speed of the market in any future research endeavors. In addition, we suggest controlling for the age of a firm because old and well established firms may have more network linkages and thus more developed social capital than young firms which may suffer from the liability of newness (Sapienza et al., 2006).

Secondly, the relatively low $R^{2}$ values for trust building and behavioral monitoring, when compared to the other latent constructs in this paper, suggest that future research should incorporate additional theoretical antecedents (e.g. resource adaptation and modularity). In the upstream internationalization process, resource dependence may not be the most salient dimension, especially when viewed from a dyadic perspective.

Thirdly, this paper focuses on exploratory capability as a dynamic capability, from a radical innovation perspective. As we proposed in the previous section, we recommend testing the relationships between behavioral monitoring and both exploitative and exploratory capabilities.

Regarding the data, we used primary data based on senior managers' perceptions, obtained through a survey as it is difficult to obtain objective data related to specific new products' longitudinal outcomes in a new market context such as this. However, the use of primary data and longitudinal objective data definitely merits investigation as it may be possible to draw more meaningful conclusions from the findings in this way.

Regarding the consequence dimension of the revised business network internationalization model (Johanson \& Vahlne, 2009), we measured the consequences of network collaborations using firm-level dynamic capability and market performance. Related to this, we would suggest that future research controls for institutional environment (e.g. the cultural distance between network partners, knowledge distance) (Berry, Guillen, \& Zhou, 2010; Whitley, 1999) to identify how institutional factors affect the upstream internationalization process and the network positions of firms.

\section{Conclusion}

To what extent resource governance of international ventures affects dynamic capability and market performance in the high-tech firms' internationalization process? Our response is that (1) trust building positively affects (dynamic) exploratory capability, (2) exploratory capability has a strong impact on market performance and (3) this effect is moderated by network-specific experience but not by network duration. Does structural capital moderate the relationship between dynamic capability and market performance? Our answer to the question is yes, research context, the existence of the previous network tie positively and significantly moderates the relationship. Our conceptual model (see Fig. 1) integrates resource governance mechanisms and dynamic capability into the internationalization model. In the context of international technology network ventures (i.e. ITAs) within complementary high-tech industries, our findings show that social capital evidently plays a critical role in building up dynamic capability and producing superior market performance in the upstream internationalization process. By following this approach, we believe that firms can improve their dynamic capability through upstream internationalization and thus change their network positions.

\section{Appendix A. Mobile computing industry}

The market has become a worldwide phenomenon over recent years, and continues to grow. It is one of the most dynamic markets today, and the global integration and coordination of dispersed technology resources is a key aspect of how firms develop highly innovative products and reap economic benefits in short windows of time. According to Gartner (2011), worldwide Smartphone shipments grew by over 200\% between 2010 and 2012, and it is expected (see also Wingfiend \& Clark, 2011) that annual worldwide shipments will reach 1.1 billion units in 2015, exceeding the corresponding figure for shipments of personal computers. The mobile computing market can be characterized as a very high-velocity environment in terms of the rapid change and growth of the market. Fig. 3 illustrates a simplified value chain of the mobile computing market. At the upper end of the hardware side, chip design and foundry firms cooperate with chip vendors. For instance, ARM, the UK-based chipset design firm, licenses its technologies to foreign system-on-chip (SoC) firms (e.g. Qualcomm, Texas Instrument, FreeScale, Marvel, Samsung, and others) (Waters, 2011). These hardware firms compete against previously dominant "x86-based" silicon manufacturers (e.g. Intel, AMD, and VIA), which are relatively stronger in the personal computer market. Some hardware firms specialize in the design and sale of semiconductor chips (e.g. fabless semiconductors) while outsourcing the fabrication of their products to specialized manufacturers such as foundries. Other types of hardware firms produce communication units (e.g. Bluetooth and Wi-Fi), graphics processing units (e.g. graphics chips), and microcontrollers (e.g. application chips).

At the upstream end of the value chain, hardware and software firms cooperate strategically to build unique software architectures on top of hardware platforms: device manufacturers are the main customers of hardware and software firms (Catalan \& Kotzab, 2003; Dedrick, Kraemer, \& Linden, 2008). Particularly, open source operating systems (OSs) are becoming more and more popular on the market (e.g. Linux, Android, and Chrome OS architectures) instead of Nokia's Symbian OS and Microsoft's commercial Windows Mobile and Windows XP OS platforms that dominated previously (Gartner, 2010; Palmer, 2010). Based on the low-level OS platforms, numerous software firms are developing a wide range of software applications and middleware (e.g. office, communications, mail, personal information management, security, multimedia players, browsers, entertainment, location-based software, power management, audio and video solutions, and databases). OS firms often integrate key software applications with their data structures ("stacks"). The OS firms also adapt and optimize their platform technologies to suit particular chip designs from hardware firms, and vice versa. Software application platform providers often port their libraries to 
chips when hardware firms release new chip designs (e.g. Sun Microsystems' x86-based Java platform was ported to new ARMbased chips).

\section{Appendix B. Construct measurement, reliability and validity}

\begin{tabular}{|c|c|c|c|}
\hline Construct measures & Mean & SD & Outer loading \\
\hline \multicolumn{4}{|l|}{$\begin{array}{l}\text { Resource dependence }(\text { alpha }=0.675, C R=0.802, A V E=0.509) \\
\text { (strongly disagree }=1, \text { strongly agree } 7)\end{array}$} \\
\hline - This partner's technologies are crucial to my company's performance & 5.100 & 1.204 & 0.787 \\
\hline - My company relies on complementary technologies from this partner & 4.645 & 1.431 & 0.806 \\
\hline - This partner's technologies are important to my company's product development & 5.127 & 1.271 & 0.702 \\
\hline - If the partnership terminates, we will not immediately find a good alternative & 3.809 & 1.511 & 0.525 \\
\hline \multicolumn{4}{|l|}{$\begin{array}{l}\text { Trust building }(\text { alpha }=0.796, C R=0.881, A V E=0.713) \\
\text { (strongly disagree }=1, \text { strongly agree } 7 \text { ) }\end{array}$} \\
\hline - The relationship with this partner is characterized by a high level of trust & 5.255 & 1.267 & 0.888 \\
\hline - We generally trust each other to stay within the terms of the contract & 5.536 & 1.194 & 0.879 \\
\hline - We are generally skeptical of the information provided by the other party (R) & 5.164 & 1.260 & 0.760 \\
\hline \multicolumn{4}{|l|}{$\begin{array}{l}\text { Behavioral monitoring }(\text { alpha }=0.870, C R=0.906, A V E=0.708) \\
(\text { strongly disagree }=1, \text { strongly agree } 7)\end{array}$} \\
\hline - Monitor to what extent this partner follows the agreed key terms & 4.955 & 1.237 & 0.710 \\
\hline - Monitor the product development process performed by this partner & 5.009 & 1.208 & 0.862 \\
\hline - Monitor technology quality developed by this partner & 5.282 & 1.174 & 0.896 \\
\hline - Monitor this partner's development milestones for our final deliverable & 5.300 & 1.162 & 0.884 \\
\hline \multicolumn{4}{|l|}{$\begin{array}{l}\text { Exploratory capability }(\text { alpha }=0.822, C R=0.881, A V E=0.650) \\
(\text { strongly disagree }=1, \text { strongly agree } 7)\end{array}$} \\
\hline - Choose a new technological approach for processes and products & 5.318 & 1.263 & 0.723 \\
\hline - Include new aspects in the technological development processes and products & 5.464 & 0.974 & 0.804 \\
\hline - Able to acquire entirely new managerial and organizational skills & 4.973 & 1.404 & 0.841 \\
\hline - Able to acquire technologies and skills new to the company & 5.482 & 1.064 & 0.852 \\
\hline \multicolumn{4}{|l|}{$\begin{array}{l}\text { Market performance }(\text { alpha }=0.830, C R=0.870, A V E=0.529) \\
(\text { not very } \text { well }=1 \text {, very well }=7)\end{array}$} \\
\hline - Sales growth & 5.073 & 1.239 & 0.637 \\
\hline - Market share growth & 4.973 & 1.145 & 0.642 \\
\hline - Increased number of official new products launched & 4.936 & 1.152 & 0.684 \\
\hline - Increased number of new customers & 5.155 & 1.068 & 0.762 \\
\hline - Increased reputation & 5.518 & 1.064 & 0.770 \\
\hline - Increased overall performance & 5.445 & 1.028 & 0.829 \\
\hline
\end{tabular}

\section{References}

Adler, P. S., \& Kwon, S.-W. (2002). Social capital: Prospects for a new concep. The Academy of Management Review, 27(1), 17-40.

Adner, R., \& Helfat, C. E. (2003). Corporate effects and dynamic managerial capabilities. Strategic Management Journal, 24(10), 1011-1025.

Ahuja, G., \& Katila, R. (2001). Technological acquisitions and the innovation performance of acquiring firms: A iongitudinal study. Strategic Management Journal, 22(3), 197-220.

Ambrosini, V., \& Bowman, C. (2009). What are dynamic capabilities and are they a useful construct in strategic management? International Journal of Management Reviews, 11(1), 29-49.

Anand, B. N., \& Khanna, T. (2000). Do firms learn to create value? The case of alliances. Strategic Management Journal, 21(3), $295-315$.

Anderson, E., \& Gatignon, H. (1986). Modes of foreign entry: A transaction cost analysis and propositions. Journal of International Business Studies, 17(3), 1-26.

Ariño, A., de La Torre, J., \& Smith Ring, P. (2001). Relational quality: Managing trust in corporate alliances. California Management Review, 44(1), 109-131.

Armstrong, J. S., \& Overton, T. S. (1977). Estimating nonresponse bias in mail surveys. Journal of Marketing Research, 14(3), $396-402$.

Atuahene-Gima, K. (2005). Resolving the capability - Rigidity paradox in new product innovation. Journal of Marketing, 69(4), 61-83.

Aulakh, P. S., Kotabe, M., \& Sahay, A. (1996). Trust and performance in cross-border marketing partnerships: A behavioral approach. Journal of International Business Studies, 27(5), 1005-1032.

Bagozzi, R. P., \& Yi, Y. (1998). On the evaluation of structural equation models. Journal of the Academy of Marketing Science, 16(1), 74-94.

Bello, D. C., \& Gilliland, D. I. (1997). The effect of output controls, process controls, and flexibility on export channel performance. Journal of Marketing, 61(1), 2238.

Berry, H., Guillen, M. F., \& Zhou, N. (2010). An institutional approach to cross-national distance. Journal of International Business Studies, 41(9), 1460-1480.

Berthon, P., Pitt, L. F., Ewing, M. T., \& Bakkeland, G. (2003). Norms and power in marketing relationships: Alternative theories and empirical evidence. Journal of Business Research, 56(9), 699-709.

Blau, P. M. (1964). Exchange and power in social life. New York: J Wiley.

Blomqvist, K., Hurmelinna-Laukkanen, P., Nummela, N., \& Saarenketo, S. (2008). The role of trust and contracts in the internationalization of technology-intensive born globals. Journal of Engineering and Technology Management, 25(1-2), 123-135.

Blomqvist, K., Hurmelinna, P., \& Seppänen, R. (2005). Playing the collaboration game right-Balancing trust and contracting. Technovation, 25(5), 497-504.

Blyler, M., \& Coff, R. W. (2003). Dynamic capabilities, social capital, and rent appropriation: Ties that split pies. Strategic Management Journal, 24(7), 677-686.

Bobillo, A. M., Sanz, J. A. R., \& Gaite, F. T. (2006). Innovation investment, competitiveness, and performance in industrial firms. Thunderbird International Business Review, 48(6), 867-890.

Buckley, P. J., \& Casson, M. C. (1988). A theory of cooperation in international business. In F. J. Contractor \& L. Peter (Eds.), Cooporative strategies in international business (1st ed., pp. 31-53). Lexington: Lexington Books.

Buckley, P. J., \& Casson, M. C. (2009). The internalisation theory of the multinational enterprise: A review of the progress of a research agenda after 30 years. Journal of International Business Studies, 40(9), 1563-1580. 
Calantone, R. J., Cavusgil, S. T., \& Zhao, Y. (2002). Learning orientation, firm innovation capability, and firm performance. Industrial Marketing Management, 31(6), $515-524$.

Cannon, J., Achrol, R., \& Gundlach, G. (2000). Contracts, norms, and plural form governance. Journal of the Academy of Marketing Science, 28(2), 180-194.

Cantwell, J., \& Narula, R. (2001). The eclectic paradigm in the global economy. International Journal of Economics of Business, 8(2), 155-172.

Capaldo, A. (2007). Network structure and innovation: The leveraging of a dual network as a distinctive relational capability. Strategic Management Journal, 28(6), 585-608.

Carson, S. J., Madhok, A., \& Wu, T. (2006). Uncertainty, opportunism, and governance: The effects of volatility and ambiguity on formal and relational contracting. Academy of Management Journal, 49(5), 1058-1077.

Catalan, M., \& Kotzab, H. (2003). Assessing the responsiveness in the danish mobile phone supply chain. International Journal of Physical Distribution \& Logistics Management, 33(8), 668-685.

Cheng, J. L. C., \& Bolon, D. S. (1993). The management of multinational R\&D - A neglected topic in international business research. Journal of International Business Studies, 24(1), 1-18.

Chesbrough, H. W. (2003). Open innovation (1st ed.). Boston: Harvard Business School Press.

Chesbrough, H. W. (2007). Why companies should have open business models. MIT Sloan Management Review, 48(2), 22-28.

Chin, W. W. (1988). The partial least squares approach to structural equation modeling. In G. A. Marcoulides (Ed.), Modern methods for business research (pp. 295336). NJ: Lawrence Erlbaum.

Ciabuschi, H., \& Martin, O. M. (2011). Internal embeddedness, headquarters involvement, and innovation importance in multinational enterprises. Journal of Management Studies, 48(7), 1621-1639.

Cohen, W. M., \& Levinthal, D. A. (1990). Absorptive capacity: A new perspective on learning and innovation. Administrative Science Quarterly, 35(1), 125-152.

Coleman, J. S. (1988). Social capital in the creation of human capital. American Journal of Sociology, 94, 95-120.

Conner, K. R., \& Prahalad, C. K. (1996). A resource-based theory of the firm: Knowledge versus opportunism. Organization Science, 7(5), 477-501.

Contractor, F. J., \& Lorange, P. (2002). Cooperative strategies and alliances in international business. Amsterdam: Pergamon.

Contractor, F. J., \& Ra, W. (2002). How knowledge attributes influence alliance governance choices: A theory development note. Journal of International Management, 8(1), 11-27.

Contractor, F. J., Woodley, J. A., \& Piepenbrink, A. (2011). How tight an embrace? Choosing the optimal degree of partner interaction in alliances based on risk, technology characteristics, and agreement provisions. Global Strategy Journal, 1(1-2), 67-85.

Coviello, N., \& Munro, H. (1997). Network relationships and the internationalisation process of small software firms. International Business Review, 6(4), $361-386$.

Das, T. K. (2005). Deceitful behaviors of alliance partners: Potential and prevention. Management Decision, 43(5), 706-719.

Das, T. K., \& Rahman, N. (2010). Determinants of partner opportunism in strategic alliances: A conceptual framework. Journal of Business and Psychology, 25(1), 5574.

Das, T. K., \& Teng, B.-S. (2002). Alliance constellations: A social exchange perspective. Academy of Management Review, 27(3), 445-456.

Das, T. K., \& Teng, B.-S. (2003). Partner analysis and alliance performance. Scandinavian Journal of Management, 19(3), 279-308.

Dedrick, J., Kraemer, K. L., \& Linden, G. (2008). Who profits from innovation in global value chains? A study of the ipod and notebook pcs, Industry Studies Annual Conference Boston: Alfred P. Sloan Foundation. pp. 1-33.

Dyer, J. H., \& Singh, H. (1998). The relation view: Cooperative strategy and sources of international competitive advantage. Academy of Management Review, 23(4), $660-679$.

Eisenhardt, K. M., \& Martin, J. A. (2000). Dynamic capabilities: What are they? Strategic Management Journal, 21(10/11), 1105-1121.

Eisenhardt, K. M., \& Tabrizi, B. N. (1995). Accelerating adaptive processes: Product innovation in the global computer industry. Administrative Science Quarterly, 40(1), 84-110.

Ellonen, H.-K., Jantunen, A., \& Kuivalainen, O. (2011). The role of dynamic capabilities in developing innovation-related capabilities. International Journal of Innovation Management, 15(3), 459-478.

Ernst, D., \& Bamford, J. (2005). Your alliances are too stable. Harvard Business Review, 83(6), 133-141.

Faems, D., Janssens, M., Bouwen, R., \& Van Looy, B. (2006). Governing explorative R\&D alliances: Searching for effective strategies. Management Revue, $17(1)$, 9-21.

Faems, D., Janssens, M., Madhok, A., \& van Looy, B. (2008). Toward an integrative respective on alliance governance: Connecting contract design, trust dynamics, and contract application. Academy of Management Journal, 51(6), 1053-1078.

Figueira-de-Lemos, F., Johanson, J., \& Vahlne, J.-E. (2011). Risk management in the internationalization process of the firm: A note on the Uppsala model. Journal of World Business, 46(2), 143-153.

Fornell, C., \& Bookstein, F. L. (1982). Two structural equation models: Lisrel and PLS applied to consumer exit-voice theory claes. Journal of Marketing Research, 19(4), 440-452.

Fornell, C., \& Larcker, D. F. (1981). Evaluating structural equation models with unobservable variables and measurement error. Journal of Marketing Research, 18(1), 39-50.

Galbraith, J. R. (1982). Designing the innovating organization. Organizational Dynamics, 10(3), 4-25

Ganesan, S. (1994). Determinants of long-term orientation in buyer-seller relationships. Journal of Marketing, 58(2), 1-19.

Gartner. (2010). Gartner says worldwide mobile phone sales grew 17 per cent in first quarter 2010 Retrieved from: http://www.gartner.com/it/page.jsp?id=1372013.

Gartner. (2011). Gartner says Android to command nearly half of worldwide smartphone operating system market by year-end 2012 Retrieved from http:// www.gartner.com/it/page.jsp?id=1622614.

Geisser, S. (1975). The predictive sample reuse method with applications. Journal of the American Statistical Association, 70(350), 320-328.

Gerwin, D. (2004). Coordinating new product development in strategic alliances. The Academy of Management Review, 29(2), 241-257.

Götz, O., Liehr-Gobbers, K., \& Krafft, M. (2010). Evaluation of structural equation models using the partial least squares (PLS) approach. In V. E. Vinzi, W. W. Chin, J. Henseler, \& H. Wang (Eds.), Handbook of partial least squares. Berlin: Springer.

Granovetter, M. (1985). Economic action and social structure: The problem of embeddedness. American Sociological Review, 91(3), 481-510.

Griffith, D. A., Cavusgil, S. T., \& Xu, S. (2008). Emerging themes in international business research. Journal of International Business Studies, 39(7), $1220-1235$.

Griffith, D. A., \& Harvey, M. G. (2001). A resource perspective of global dynamic capabilities. Journal of International Business Studies, 32(3), 597-606.

Griffith, D. A., Yalcinkaya, G., \& Calantone, R. J. (2010). Do marketing capabilities consistently mediate effects of firm intangible capital on performance across institutional environments? Journal of World Business, 45(3), 217-227.

Gruber, M., Heinemann, F., Brettel, M., \& Hungeling, S. (2010). Configurations of resources and capabilities and their performance implications: An exploratory study on technology ventures. Strategic Management Journal, 31(12), 1337-1356.

Gulati, R., Lavie, D., \& Singh, H. (2009). The nature of partnering experience and the gains from alliances. Strategic Management Journal, $30(11), 1213-1233$.

Gulati, R., \& Nickerson, J. A. (2008). Interorganizational trust, governance choice, and exchange performance. Organization Science, 19(5), 688-708

Gulati, R., \& Singh, H. (1998). The architecture of cooperation: Managing coordination costs and appropriation concerns in strategic alliances. Administrative Science Quarterly, 43, 781-814.

Gulati, R., \& Sytch, M. (2008). Does familiarity breed trust? Revisiting the antecedents of trust. Managerial and Decision Economics, 29(2-3), 165-190.

Ha, H., \& Rothaermel, F. T. (2005). The effect of general and partner-specific alliance experience on joint r\&d project performance. Academy of Management Journal, $48(2), 332-345$

Hagedoorn, J. (2002). Inter-firm R\&D partnerships: An overview of major trends and patterns since 1960. Research Policy, 31(4), 477-492.

Hair, J. F., Sarstedt, M., Pieper, T., \& Ringle, C. M. (2012). Applications of partial least squares path modeling in management journals: A review of past practices and recommendations for future applications. Long Range Planning

Håkansson, H., \& Snehota, I. (1995). Developing relationships in business networks (1st ed.). New York: Routledge.

Hallén, L., Johanson, J., \& Seyed-Mohamed, N. (1991). Interfirm adaptation in business relationships. Journal of Marketing, 55(2), 29-37. 
Harrison, J. S., Hitt, M. A., Hoskisson, R. E., \& Ireland, R. D. (2001). Resource complementarity in business combinations: Extending the logic to organizational alliances. Journal of Management, 27, 679-690.

Heide, J. B. (1994). Interorganizational governance in marketing channels. Journal of Marketing, 58(1), 71-85.

Heide, J. B., Wathne, K. H., \& Rokkan, A. (2007). Interfirm monitoring, social contracts, and relationship outcomes. Journal of Marketing Research, 44(3), $425-433$.

Helfat, C., Finkelstein, S., Mitchell, W., Peteraf, M., Singh, H., Teece, D., et al. (2007). Dynamic capabilities: Understanding strategic change in organizations (1st ed.). Oxford: Blackwell.

Henderson, R. M., \& Clark, K. B. (1990). Architectural innovation: The reconfiguration of existing product technologies and the failure of established firms. Administrative Science Quarterly, 35(1), 9-30.

Henley, A. B., Shook, C. L., \& Peterson, M. (2006). The presence of equivalent models in strategic management research using structural equation modeling. Organizational Research Methods, 9(4), 516-535.

Henseler, J., Ringle, C. M., \& Sinkovics, R. R. (2009). The use of partial least squares path modeling in international marketing. In Sinkovics, R. R., \& Ghauri, P. N. (Eds.), New challenges to international marketing (vol. 20, pp. 277-320). Bingley: Emerald.

Hill, C. W. L., \& Rothaermel, F. T. (2003). The performance of incumbent firms in the face of radical technological innovation. Academy of Management Review, 28(2), $257-274$.

Hoetker, G., \& Mellewigt, T. (2009). Choice and performance of governance mechanisms: Matching alliance governance to asset type. Strategic Management Journal, 30(10), 1025-1044.

Hulland, J. (1999). Use of partial least squares (PLS) in strategic management research: A review of four recent studies. Strategic Management Journal, 20(2), 195204.

Inkpen, A. C. (2000). Learning through joint ventures: A framework of knowledge acquisition. Journal of Management Studies, 37(7), $1019-1043$.

Inkpen, A. C., \& Currall, S. C. (2004). The coevolution of trust, control, and learning in joint ventures. Organization Science, 15(5), 586-599.

Inkpen, A. C., \& Tsang, E. W. K. (2005). Social capital, networks, and knowledge transfer. The Academy of Management Review, 30(1), $146-165$.

Jacobides, M. G., Knudsen, T., \& Augier, M. (2006). Benefiting from innovation: Value creation, value appropriation and the role of industry architectures. Research Policy, 35(8), 1200-1221.

Jantunen, A., Puumalainen, K., Saarenketo, S., \& Kyläheiko, K. (2005). Entrepreneurial orientation, dynamic capabilities and international performance. Journal of International Entrepreneurship, 3(3), 223-243.

Jaworski, B., Kohli, A. K., \& Sahay, A. (2000). Market-driven versus driving markets. Journal of the Academy of Marketing Science, 28(1), 45-54.

Jean, R.-J.B., Sinkovics, R. R., \& Cavusgil, S. T. (2010). Enhancing international customer-supplier relationships through it resources: A study of Taiwanese electronic suppliers. Journal of International Business Studies, 41(7), 1218-1239.

Johanson, J., \& Vahlne, J.-E. (1977). The internatinoalization process of firms: A model of knowledge development and increasing foriegn market commitment. Journal of International Business Studies, 8, 23-32.

Johanson, J., \& Vahlne, J.-E. (1990). The mechanisms of internationalisation. International Marketing Review, 7(4), 11-24.

Johanson, J., \& Vahlne, J.-E. (2006). Commitment and opportunity development in the internationalization process: A note on the Uppsala internationalization process model. Management International Review, 46(2), 165-178.

Johanson, J., \& Vahlne, J.-E. (2009). The Uppsala internationalization process model revisited: From liability of foreignness to liability of outsidership. Journal of International Business Studies, 40(9), 1411-1431.

Johanson, J., \& Wiedersheim-Paul, F. (1975). The internationalization process of the firm - four Swedish cases. Journal of management studies. Journal of Management Studies, 12(3), 305-323.

Kale, P., Singh, H., \& Perlumutter, H. (2000). Learning and protection of proprietary assets in strategic alliances: Building relational capital. Strategic Management Journal, 21(3), 217-237.

Kanter, R. M. (1984). When a thousand flowers bloom: Structural, collective, and social conditions for innovation in organizations. In Staw, B. M., \& Cummings, L. L. (Eds.), Research in organizational behavior (vol. 10, pp. ). ). Greenwich: JAI Press.

Kim, T.-Y., Oh, H., \& Swaminathan, A. (2006). Framing interorganizational network change: A network inertia perspective. Academy of Management Review, 31(3), 704-720.

Kirsch, L. J., Sambamurthy, V., Ko, D.-G., \& Purvis, R. L. (2002). Controlling information systems development projects: The view from the client. Management Science, 48(4), 484-498.

Kishimoto, C. (2004). Clustering and upgrading in global value chains: The Taiwanese personal computer industry. In H. Schmitz (Ed.), Local enterprises in the global economy: Issues of governance and upgrading (pp. 233-264). Cheltenham: Edward Elgar.

Kogut, B., \& Zander, U. (1992). Knowledge of the firm, combinative capabilities, and the replication of technology. Organization Science, 3(3), 383-397.

Kogut, B., \& Zander, U. (1993). Knowledge of the firm and the evolutionary theory of the multinational corporation. Journal of International Business Studies, 24(4), 625-645.

Koka, B. R., \& Prescott, J. E. (2002). Strategic alliances as social capital: A multidimensional view. Strategic Management Journal, 23(9), 795-816.

Kotabe, M., \& Swan, K. S. (1995). The role of strategic alliances in high-technology new product development. Strategic Management Journal, 16(8), 621-636.

Lages, L. F., Silva, G., \& Styles, C. (2009). Relationship capabilities, quality, and innovation as determinants of export performance. Journal of International Marketing, $17(4), 47-70$.

Lavie, D. (2006). The competitive advantage of interconnected firms: An extension of the resource-based view. Academy of Management Review, 31(3), 638-658.

Lavie, D. (2007). Alliance portfolios and firm performance: A study of value creation and appropriation in the U.S. Software industry. Strategic Management Journal, 28(12), 1187-1212.

Lawson, B., \& Samson, D. (2001). Developing innovation capability in organizations: A dynamic cpabability approach. International Journal of Innovation Management, 5(3), 377-400.

Levine, S., \& White, P. E. (1961). Exchange as a conceptual framework for the study of interorganizational relationships. Administrative Science Quarterly, 5(4), 583601.

Levinthal, D. A., \& March, J. G. (1993). The myopia of learning. Strategic Management Journal, 14, 95-112.

Lisboa, A., Skarmeas, D., \& Lages, C. (2011). Entrepreneurial orientation, exploitative and explorative capabilities, and performance outcomes in export markets: A resource-based approach. Industrial Marketing Management, 40(8), 1274-1284.

Liu, C.-L.E., Ghauri, P. N., \& Sinkovics, R. R. (2010). Understanding the impact of relational capital and organizational learning on alliance outcomes. Journal of World Business, 45(3), 237-249.

Lorenz, E. (1999). Trust, contract and economic cooperation. Cambridge Journal of Economics23(3) 301-301-315.

Lusch, R. F., \& Brown, J. R. (1996). Interdependency, contracting, and relational behavior in marketing channels. Journal of Marketing, 60(4), 19-38.

Lyles, M. A., \& Salk, J. E. (2007). Knowledge acquisition from foreign parents in international joint ventures: An empirical examination in the Hungarian context. Journal of International Business Studies, 38(1), 3-18.

Madhok, A. (1995). Opportunism and trust in joint venture relationships: An exploratory study and model. Scandinavian Journal of Management, 11(1), $57-74$.

Madhok, A. (2006). Revisiting multinational firms' tolerance for joint ventures: A trust-based approach. Journal of International Business Studies, 37, $30-43$.

Malhotra, N., \& Hinings, C. R. (2010). An organizational model for understanding internationalization processes. Journal of International Business Studies, 41(2), 330-349.

March, J. G. (1991). Exploration and exploitation in organizational learning. Organization Science, 2(1), 71-87.

Marsden, P., \& Campbell, K. (1984). Measuring tie strength. Social Forces, 63, 482-501.

Mathieu, J. E., \& Zajac, D. M. (1990). A review and meta-analysis of the antecedents, correlates, and consequences of organizational commitment. Psychological Bulletin, 108(2), 171-194. 
Mayer, K. J., \& Salomon, R. M. (2006). Capabilities, contractual hazards, and governance: Integrating resource-based and transaction cost perspectives. Academy of Management Journal, 49(5), 942-959.

Mitchell, W., \& Singh, K. (1996). Survival of businesses using collaborative relationships to commercialize complex goods. Strategic Management Journal, 17(3), $169-195$.

Mowery, D. C., Oxley, J. E., \& Silverman, B. S. (1996). Strategic alliances and interfirm knowledge transfer. Strategic Management Journal, 17(S1), 77L 91.

Mudambi, R. (2007). Book review: Offshoring: Economic geography and the multinational firm. Journal of International Business Studies, 38 (1), 206.

Mudambi, R., \& Navarra, P. (2004). Is knowledge power? Knowledge flows, subsidiary power and rent-seeking within MNCs. Journal of International Business Studies, 35(5), 385-406.

Mudambi, R., \& Swift, T. (2011). Leveraging knowledge and competencies across space: The next frontier in international business. Journal of International Management, 17(3), 186-189.

Nachum, L. (2003). Liability of foreignness in global competition? Financial service affiliates in the city of London. Strategic Management Journal, 24(12), 11871208.

Nahapiet, J., \& Ghoshal, S. (1998). Social capital, intellectual capital, and the organizational advantage. The Academy of Management Review, 23(2), 242-266.

Newey, L. R., \& Zahra, S. A. (2009). The evolving firm: How dynamic and operating capabilities interact to enable entrepreneurship. British Journal of Management, 20(S1), S81-S100.

Ohmae, K. (1989). The global logic of strategic alliances. Harvard Business Review, 67(2), 143-154.

Oxley, J. E. (1997). Appropriability hazards and governance in strategic alliances: A transaction cost approach. Journal of Law and Economics, E Organization, 13(2), 387-409.

Oxley, J. E., \& Sampson, R. C. (2004). The scope and governance of international R\&D alliances. Strategic Management Journal, $25(8-9), 723-749$.

Palmer, M. (2010, 19 May). Android overtakes windows in smartphones. Financial Times.

Pfeffer, J., \& Salancik, G. R. (1978). The external control of organizations. New York: Harper \& Row.

Podolny, J. M. (1994). Market uncertainty and the social character of economic exchange. Administrative Science Quarterly, 39(3), 458-483.

Podsakoff, P. M., \& Organ, D. W. (1986). Self-reports in organizational research: Problems and prospects. Journal of Management, 12(4), $531-544$.

Poppo, L., \& Zenger, T. (2002). Do formal contracts and relational governance function as substitutes or complement? Strategic Management Journal, 23(8), 707725.

Richey, R. G., Daugherty, P. J., \& Roath, A. S. (2007). Firm technological readiness and complementarity: Capabilities impacting logistics service competency and performance. Journal of Business Logistics, 28(1), 195-228.

Ring, P. S., \& van de Ven, A. H. (1994). Developmental processes of cooperative interorganizational relationships. Academy of Management Review, 19(1), 90118.

Robins, J. A., Tallman, S., \& Fladmoe-Lindquist, K. (2002). Autonomy and dependence of international cooperative ventures: An exploration of the strategic performance of U.S. Ventures in mexico. Strategic Management Journal, 23(10), 881-901.

Rong, B., \& Wilkinson, I. F. (2011). What do managers' survey reponses mean and what affects them? The case of market orientation and firm performance. Australasian Marketing Journal (AMJ), 19(3), 137-147.

Sampson, R. C. (2004). Organizational choice in R\&D alliances: Knowledge-based and transaction cost perspectives. Management and Decision Economics, 25, 421436.

Santangelo, G. D., \& Meyer, K. E. (2011). Extending the internationalization process model: Increases and decreases of MNE commitment in emerging economies. Journal of International Business Studies, 42(7), 894-909.

Sapienza, H. J., Autio, E., George, G., \& Zahra, S. A. (2006). A capabilities perspective on the effects of early internationalization on firm survival and growth. The Academy of Management Review, 31(4), 914-933.

Sarkar, M., Echambadi, R., Cavusgil, S. T., \& Aulakh, P. S. (2001). The influence of complementarity, compatibility, and relationship capital on alliance performance. Journal of the Academy of Marketing Science, 29(4), 358-373.

Selnes, F., \& Sallis, J. (2003). Promoting relationship learning. The Journal of Marketing, 67(3), 80-95

Shapiro, C., \& Varian, H. R. (1999). Information rule. Boston: Harvard Business School Press.

Silverman, B. S., \& Baum, J. A. C. (2002). Alliance-based competitive dynamics. Academy of Management Journal, 45(4), $791-806$.

Simonin, B. L. (1999). Ambiguity and the process of knowledge transfer in strategic alliances. Strategic Management Journal, 20(7), 535-623.

Stone, M. (1974). Cross-validatory choice and assessment of statistical predictions. Journal of the Royal Statistical Society, Series B (Methodological), 36(2), 111147.

Svejenova, S. (2006). How much does trust really matter? Some reflections on the significance and implications of madhok's trust-based approach. Journal of International Business Studies, 37(1), 12-20.

Swoboda, B., Meierer, M., Foscht, T., \& Morschett, D. (2011). International SME alliances: The impact of alliance building and configurational fit on success. Long Range Planning, 44(4), 271-288.

Teece, D. J. (1996). Firm organization, industrial structure, and technological innovation. Journal of Economic Behavior E' Organization, 31(6), 193-224.

Teece, D. J. (2007). Explicating dynamic capabilities: The nature and microfoundations of (sustainable) enterprise performance. Strategic Management Journal, 28(13), 1319-1350

Teece, D. J., \& Pisano, G. P. (1994). The dynamic capabilities of firms: An introduction Industrial and Corporate Change, 3(3), 537-556.

Teece, D. J., Pisano, G. P., \& Shuen, A. (1997). Dynamic capability and strategic management. Strategic Management Journal, 18(7), 509-533.

Tenenhaus, M., Vinzi, V. E., Chatelin, Y.-M., \& Lauro, C. (2005). PLS path modeling. Computational Statistics \& Data Analysis, 48(1), 159-205.

Thorgren, S., Wincent, J., \& Eriksson, J. (2011). Too small or too large to trust your partners in multipartner alliances? The role of effort in initiating generalized exchanges. Scandinavian Journal of Management, 27(1), 99-112.

Tsai, W., \& Ghoshal, S. (1998). Social capital and value creation: The role of intrafirm networks. Academy of Management Journal, 41(4), 464-476.

Tsang, E. W. K. (2002). Acquiring knowledge by foreign partners from international joint ventures in a transition economy: Learning-by-doing and learning myopia. Strategic Management Journal, 23(9), 835-854.

Tsang, E. W. K., Yip, P. S. L., \& Toh, M. H. (2008). The impact of R\&D on value added for domestic and foreign firms in a newly industrialized economy. International Business Review, 17(4), 423-441.

Vahlne, J.-E., Ivarsson, I., \& Johanson, J. (2011). The tortuous road to globalization for volvo's heavy truck business: Extending the scope of the Uppsala model. International Business Review, 20(1), 1-14.

Venkatraman, N., \& Ramanujam, V. (1986). Measurement of business performance in strategy research: A comparison of approaches. Academy of Management Review, 11(4), 801-814.

Vorhies, D. W., Morgan, R. E., \& Autry, C. W. (2009). Product-market strategy and the marketing capabilities of the firm: Impact on market effectiveness and cash flow performance. Strategic Management Journal, 30(12), 1310-1334.

Waters, R. (2011, January 6). Microsoft needs to rethink tablets. Financial Times.

White, S., \& Lui, S.S.-Y. (2005). Distinguishing costs of cooperation and control in alliances. Strategic Management Journal, 26(10), 913-932.

Whitley, R. (1999). Divergent capitalisms: The social structuring and change of business systems. Oxford: Oxford University Press.

Williamson, O. E. (1979). Transaction-cost economics: The governance of contractual relations. Journal of Law and Economics, 22(2), 233-261.

Williamson, O. E. (1981). The economics of organization: The transaction cost approach. American Journal of Sociology, 87(3), 548-577.

Wingfiend, N., \& Clark, D. (2011). Microsoft alliance with Intel shows age. The Wall Street Journal.

Winter, S. G. (2003). Understanding dynamic capabilities. Strategic Management Journal, 24(10), 991-995.

Wold, H. (1975). Path models with latent variables: The nipals approach. In H. M. Blalock, A. Aganbegian, F. M. Borodkin, R. Boudon, \& V. Capecchi (Eds.), Quantitative sociology (pp. 307-359). New York: Acadmic. 
Yalcinkaya, G., Calantone, R. J., \& Griffith, D. A. (2007). An examination of exploration and exploitation capabilities: Implications for product innovation and market performance. Journal of International Marketing, 15(4), 63-93.

Yamin, M., \& Anderson, U. (2011). Subsidiary importance in the MNC: What role does internal embeddedness play? International Business Review, 20(2), 151162.

Yilmaz, C., \& Kabadayi, E. T. (2006). The role of monitoring in interfirm exchange: Effects on partner unilateral cooperation. Journal of Business Research, 59(12), $1231-1238$.

Zhou, K. Z., \& Wu, F. (2010). Technological capability, strategic flexibility, and product innovation. Strategic Management Journal, 31(5), 547-561.

Zollo, M., Reuer, J. J., \& Singh, H. (2002). Interorganizational routines and performance in strategic alliances. Organization Science, 13(6), 701-713. 